Linköping Studies in Science and Technology

Dissertation No. 1996

\title{
Phase stability and defect structures in \\ [Ti,Al]N hard coatings
}

Katherine M Calamba

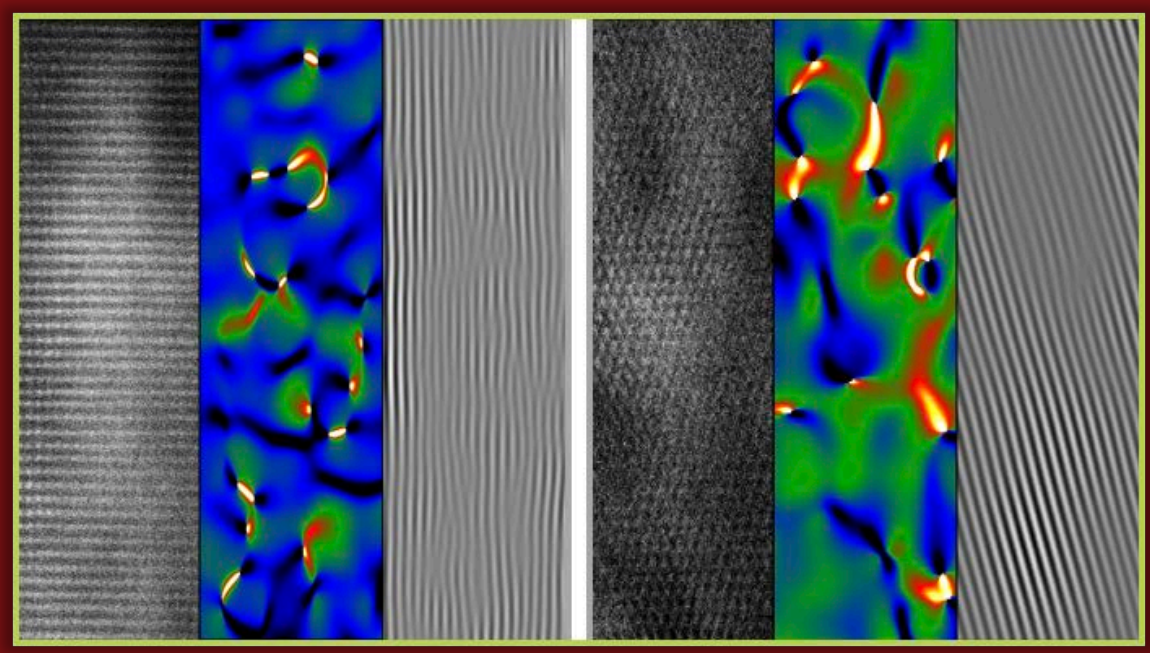

LINKÖPING

UNIVERSITY 
Linköping Studies in Science and Technology

Dissertation No. 1996

\section{Phase stability and defect structures in ( $\mathbf{T i}, \mathbf{A l}) \mathbf{N}$ hard coatings}

Katherine Calamba

Nanostructured Materials

Department of Physics, Chemistry, and Biology (IFM)

Linköping University, Sweden

Part of

Joint European Doctoral Program in Materials Science and Engineering (DocMASE) in collaboration of Institute Jean Lamour

University of Lorraine, France 
(C) [Katherine Calamba, 2019]

Printed in Sweden by LiU-Tryck, Linköping 2019

ISSN: 0345-7524

ISBN: 978-91-7685-041-1 


\section{Abstract}

This study highlights the role of nitrogen vacancies and defect structures in engineering hard coatings with enhanced phase stability and mechanical properties for high temperature applications. Titanium aluminum nitride (Ti,Al)N based materials in the form of thin coatings has remained as an outstanding choice for protection of metal cutting tools due to its superior oxidation resistance and high-temperature wear resistance. High-temperature spinodal decomposition of metastable (Ti,Al)N into coherent c-TiN and c-AlN $\mathrm{nm}$-sized domains results in high hardness at elevated temperatures. Even higher thermal input leads to transformation of c-AlN to w-AlN, which is detrimental to the mechanical properties of the coating. One mean to delay this transformation is to introduce nitrogen vacancies.

In this thesis, I show that by combining a reduction of the overall $\mathrm{N}$-content of the c-(Ti,Al) $\mathrm{N}_{\mathrm{y}}(\mathrm{y}<1)$ coating with a low substrate bias voltage during cathodic arc deposition an even more pronounced delay of the c-AlN to w-AlN phase transformation is achieved. Under such condition, age hardening is retained until $1100{ }^{\circ} \mathrm{C}$, which is the highest temperature reported for (Ti,Al)N films. During cutting operations, the wear mechanism of the cathodic-arc-deposited c- $\left(\mathrm{Ti}_{0.52} \mathrm{Al}_{0.48}\right) \mathrm{N}_{\mathrm{y}}$ with $\mathrm{N}$-contents of $\mathrm{y}=0.92,0.87$, and 0.75 films are influenced by the interplay of nitrogen vacancies, microstructure, and chemical reactions with the workpiece material. The $\mathrm{y}=0.75$ coating contains the highest number of macroparticles and has an inhomogeneous microstructure after machining, which lower its flank and crater wear resistance. Age hardening of the $\mathrm{y}=0.92$ sample causes its superior flank wear resistance while the dense structure of the $y=0.87$ sample prevents chemical wear that results in excellent crater wear resistance.

Heteroepitaxial c- $\left(\mathrm{Ti}_{1-\mathrm{x}}, \mathrm{Al}_{\mathrm{x}}\right) \mathrm{N}_{\mathrm{y}}(\mathrm{y}=0.92,0.79$, ando.67) films were grown on $\mathrm{MgO}(001)$ and (111) substrates using magnetron putter deposition to examine the details of their defect structures during spinodal decomposition. At $900{ }^{\circ} \mathrm{C}$, the films decompose to form coherent c-AlN- and c-TiN- rich domains with elongated shape along the elastically soft $<001>$ direction. Deformation maps show that most strains occur near the interface of the segregated domains and inside the c-TiN domains. Dislocations favorably aggregate in c-TiN rather than c-AlN because the later has stronger directionality of covalent chemical bonds. At elevated temperature, the domain size of (001) and (111)- oriented c$(\mathrm{Ti}, \mathrm{Al}) \mathrm{N}_{\mathrm{y}}$ films increases with the nitrogen content. This indicates that there is a delay in coarsening due to the presence of more $\mathrm{N}$ vacancies in the film. 
The structural and functional properties $\left(\mathrm{Ti}_{1-\mathrm{x}}, \mathrm{Al}_{\mathrm{x}}\right) \mathrm{N}_{\mathrm{y}}$ are also influenced by its $\mathrm{Al}$ content $(\mathrm{x})$. TiN and $\left(\mathrm{Ti}_{1-\mathrm{x}}, \mathrm{Al}_{\mathrm{x}}\right) \mathrm{N}_{\mathrm{y}}(\mathrm{y}=1, \mathrm{x}=0.63$ and $\mathrm{x}=0.77)$ thin films were grown on $\mathrm{MgO}(111)$ substrates using magnetron sputtering technique. Both TiN and $\mathrm{Ti}_{0.27} \mathrm{Al}_{0.63} \mathrm{~N}$ films are single crystals with cubic structure. $\left(\mathrm{Ti}_{0.23}, \mathrm{Al}_{\text {o.77}}\right) \mathrm{N}$ film has epitaxial cubic structure only in the first few atomic layers then it transitions to an epitaxial wurtzite layer, with an orientation relationship of $\mathrm{c}-\left(\mathrm{Ti}_{0.23}, \mathrm{Al}_{0.77}\right) \mathrm{N}(111)[1-10] \mid \mathrm{w}-\left(\mathrm{Ti}_{0.23}, \mathrm{Al}_{0.77}\right) \mathrm{N}(0001)[11-20]$. The $\mathrm{w}-\left(\mathrm{Ti}_{0.23}, \mathrm{Al}_{0.77}\right) \mathrm{N}$ shows phase separation of coherent $\mathrm{nm}$-sized domains with varying chemical composition during growth. After annealing at high temperature, the domains in $\mathrm{w}-\left(\mathrm{Ti}_{0.23}, \mathrm{Al}_{0.77}\right) \mathrm{N}$ have coarsened. The domains in $\mathrm{w}-\left(\mathrm{Ti}_{0.23}, \mathrm{Al}_{0.77}\right) \mathrm{N}$ are smaller compared to the domains in c- $\left(\mathrm{Ti}_{0.27}, \mathrm{Al}_{0.63}\right) \mathrm{N}$ film that has undergone spinodal decomposition. The results that emerged from this thesis are of great importance in the cutting tool industry and also in the microelectronics industry, because the layers examined have properties that are well suited for diffusion barriers. 


\section{Populärvetenskaplig Sammanfattning}

Nitrider av övergångsmetaller är intressanta på grund av deras goda elektriska, termodynamiska och mekaniska egenskaper. Bland metallnitriderna uppvisar titanaluminiumnitrid (Ti,Al)N särskilt hög slitstyrka vid högtemperaturtillämpningar. Detta beror på en kombination av oxidationsbeständighet och åldringshärdning. Det senare kommer av ett spinodal sönderfall av den metastabila c-(Ti,Al)N fasen till c-TiN och c-AlN vid förhöjda temperaturer. Ytterligare temperaturökning resulterar $i$ en transformation av c-AlN till dess mest stabila form, dvs wurtzit (w-AlN). Närvaro av wurtzit i skikten är menligt för dess mekaniska egenskaper. Fördröjning av fastransformationen av AlN är nödvändig för att förbättra den termiska stabiliteten och åstadkomma förbättringar av skiktets mekaniska egenskaper vid höga temperaturer. I denna avhandling har mikrostrukturen hos (Ti,Al)N-skikt studerats på detaljnivå, eftersom detta starkt påverkar skiktens fysikaliska egenskaper.

I den första delen av avhandlingen undersöks inverkan av substratpotentialen som används under tillväxt med katodförångning och kvävevakansinnehållet på den termiska stabiliteten hos $\left(\mathrm{Ti}_{0.54}, \mathrm{Al}_{0.46}\right) \mathrm{N}_{\mathrm{y}}(\mathrm{y}<1)$ skikt. Katodförångning används ofta för beläggning av skikt inom skärverktygsindustrin på grund av att mycket god vidhäftning av skiktet till substratet erhålls och dess höga deponeringshastighet. $\left(\mathrm{Ti}_{0.54}, \mathrm{Al}_{0.46}\right) \mathrm{N}_{0.87}$-skikt med lågt kväveinnehåll växtes med olika substratpotential, vilket medförde signifikanta förändringar av deras mikrostruktur. En fördröjning i fastransformationen av c-AlN till w-AlN uppnåddes genom att använda låg substratpotential under beläggningen och låg N-halt i skikten. Åldringshärdningsen behålls till $1100{ }^{\circ} \mathrm{C}$, dvs den högsta temperatur rapporterad för (Ti,Al)N. Vid svarvning påverkas också nötningsmekanismerna hos $\left(\mathrm{Ti}_{0.52}, \mathrm{Al}_{0.48}\right) \mathrm{N}_{\mathrm{y}}$-skikt på grund av samspelet mellan kvävevakanser, mikrostruktur och kemiska reaktioner med arbetsstycket .

Det finns många studier av effekten av deponeringsparametrar på egenskapen hos (Ti,Al)N skikt. Emellertid är mikrostrukturen för de flesta syntetiserade filmerna inte så välordnad vilket försvårar och ofta omöjliggör studier på en tillräckligt detaljerad nivå, t.ex. gällande defektstrukturer och termodynamik såväl som motsvarande funktionella egenskaper. Den andra delen av denna avhandling undersöker dislokationstrukturen och utvecklingen av lokala töjningar i enkristallina (Ti,Al)N skikt. DC magnetronsputtring är den beläggningsteknik som använts då den möjliggör syntes av homogena 
mikrostrukturer och eliminerar närvaron av makropartiklar. Heteroepitaxiella $c-\left(\mathrm{Ti}_{1-\mathrm{x}}, \mathrm{Al}_{\mathrm{x}}\right) \mathrm{N}_{\mathrm{y}}(\mathrm{y}=0.92,0.79$ och 0.67$)$ skikt växtes på $\mathrm{MgO}$ (001) och (111) substrat genom magnetronsputtring och detaljerna av deras defektstrukturer under spinodal sönderdelning undersöktes. Vid $900{ }^{\circ} \mathrm{C}$ segregerar skikten och bildar koherenta c-AlN- och c-TiN-rika domäner med långsträckt form längs den elastiskt komplianta <001> riktningen. Deformationskartor visar att töjningen är lokaliserad nära gränsytorna för de segregerade domänerna samt inuti c-TiN-domänerna. Domänstorleken för c-(Ti,Al) $\mathrm{N}_{\mathrm{y}}$-skikt med tillväxtriktning (oo1) och (111) ökar med kvävehalten, d.v.s. förgrovningen fördröjs i närvaron av N-vakanser i skiktet.

$\left(\mathrm{Ti}_{1-\mathrm{x}}, \mathrm{Al}_{\mathrm{x}}\right) \mathrm{N}_{\mathrm{y}}$ skikts strukturella och funktionella egenskaperna påverkas också av dess Al-innehåll $(\mathrm{x})$. TiN och $\left(\mathrm{Ti}_{1-\mathrm{x}}, \mathrm{Al}_{\mathrm{x}}\right) \mathrm{N}(\mathrm{x}=0.63$ och $\mathrm{x}=0.77)$ skikt växtes på $\mathrm{MgO}(111)$ substrat med magnetronsputtering. Både TiN och $\left(\mathrm{Ti}_{0.27}, \mathrm{Al}_{0.63}\right) \mathrm{N}-$ skikten är enkristaller med kubisk struktur medan $\left(\mathrm{Ti}_{0.23}, \mathrm{Al}_{0.77}\right) \mathrm{N}$-skiktet har en epitaxiell kubisk struktur endast i de första atomlagren och sedan övergår till en eptitaxiell wurtzit struktur. $\mathrm{w}-\left(\mathrm{Ti}_{0.23}, \mathrm{Al}_{0.77}\right) \mathrm{N}$ visar klustring av koherenta $\mathrm{Al}$ - och Ti-rika nm-stora domäner medan c-(Ti $\left.\mathrm{Ti}_{0.27}, \mathrm{Al}_{0.63}\right) \mathrm{N}$ är kemiskt homogen efter beläggningen. Efter värmebehandling vid hög temperatur sker kemisk segregation i den kubiska filmen och långsträckta c-AlN- och c-TiN-rika domäner har bildats via spinodal sönderfall medan wurtzitfilmen har en liknande mikrostruktur som innan värmebehandlingen.

Resultaten som framkommit i denna avhandling är av stor betydelse inom skärverktygsindustrin men också mikroelektronikindustrin, eftersom de undersökta skikten har egenskaper som är väl lämpade som diffusionsbarriärer. 


\section{Résumé étendu}

Cette étude met en évidence le rôle des lacunes d'azote et des défauts structuraux dans l'ingénierie de revêtements durs à stabilité de phase améliorée et dont les propriétés mécaniques sont compatibles avec des applications à haute température. Le nitrure de titane et d'aluminium (Ti,Al)N sous forme de revêtements est un matériau de choix pour la protection des outils de coupe pour métaux en raison de sa résistance supérieure à l'oxydation et à l'usure à haute température. La décomposition spinodale à haute température de la phase métastable cubique (Ti,Al)N en domaines cohérents de taille nanométrique de c-TiN et de c-AlN donne une dureté importante aux températures élevées. Un apport thermique encore plus élevé conduit à la transformation de c-AlN en w-AlN, ce qui nuit aux propriétés mécaniques du revêtement. Un moyen de retarder cette transformation est d'introduire des lacunes d'azote.

Dans cette thèse, je montre que la combinaison d'une réduction de la teneur globale en azote du revêtement $\mathrm{c}-(\mathrm{Ti}, \mathrm{Al}) \mathrm{N}_{\mathrm{y}}(\mathrm{y}<1)$ avec une faible tension de polarisation du substrat lors du dépôt par arc cathodique induit un retard encore plus prononcé de la transformation de la phase c-AlN en w-AlN. Dans de telles conditions, le durcissement par vieillissement est conservé jusqu'à $1100{ }^{\circ} \mathrm{C}$, ce qui correspond à la température la plus élevée signalée pour les films de (Ti,Al)N. Au cours des opérations de coupe, le mécanisme d'usure des films c-(Tio.52, $\left.\mathrm{Al}_{0.48}\right) \mathrm{N}_{\mathrm{y}}$ déposés par arc cathodique avec des teneurs en $\mathrm{N}$ de $\mathrm{y}=$ 0.92, 0.87 et 0.75 est influencé par l'interaction des lacunes d'azote, de la microstructure et des réactions chimiques avec le matériau de la pièce. Le revêtement $\mathrm{y}=0.75$ contient le plus grand nombre de macroparticules et présente, après usinage, une microstructure non homogène qui en abaisse la résistance à l'usure sur les flancs et les cratères. Le durcissement par vieillissement de l'échantillon $\mathrm{y}=0.92$ entraîne une résistance supérieure à l'usure sur le flanc, tandis que la structure dense de l'échantillon $\mathrm{y}=0.87$ empêche l'usure chimique qui se traduit par une excellente résistance à l'usure sur les cratères.

Des films hétéroépitaxiés c- $\left(\mathrm{Ti}_{1-\mathrm{x}}, \mathrm{Al}_{\mathrm{x}}\right) \mathrm{N}_{\mathrm{y}}(\mathrm{y}=$ 0.92, 0.79 et 0.67$)$ ont été déposés sur des substrats de $\mathrm{MgO}(001)$ et (111) en utilisant une technique de pulvérisation magnétron pour examiner en détail les défauts structuraux pendant la décomposition spinodale. À $900{ }^{\circ} \mathrm{C}$, les films se décomposent pour former des domaines cohérents riches en c-AlN et c-TiN de forme allongée le long de la direction $<001>$. Les cartographies de déformation montrent que la 
plupart des contraintes se trouvent près de l'interface des domaines ségrégés et à l'intérieur des domaines c-TiN. Les dislocations s'agrègent favorablement dans c-TiN plutôt que dans c-AlN car ce dernier a une directionnalité plus forte des liaisons chimiques covalentes. À température élevée, la taille de domaine des films de c-(Ti,Al) $\mathrm{N}_{\mathrm{y}}$ orientés (oo1) et (111) augmente avec la teneur en azote.

Les propriétés structurelles et fonctionnelles des films de $\left(\mathrm{Ti}_{1-\mathrm{x}}, \mathrm{Al}_{\mathrm{x}}\right) \mathrm{N}_{\mathrm{y}}$ sont également influencées par leur teneur en $\mathrm{Al}(\mathrm{x})$. Des films minces de TiN et $\left(\mathrm{Ti}_{1-\mathrm{x}}, \mathrm{Al}_{\mathrm{x}}\right) \mathrm{N}(\mathrm{y}=1, \mathrm{x}=0.63$ et $\mathrm{x}=0.77)$ ont été déposés sur des substrats de $\mathrm{MgO}$ (111) en utilisant une technique de pulvérisation cathodique magnétron. Les films TiN et $\left(\mathrm{Ti}_{0.37}, \mathrm{Al}_{0.63}\right) \mathrm{N}$ sont des monocristaux à structure cubique. Le film $\left(\mathrm{Ti}_{0.23}, \mathrm{Al}_{0.77}\right) \mathrm{N}$ est épitaxié seulement dans les premières couches atomiques, puis il se transforme en une couche épitaxiée de wurtzite, avec une relation d'orientation de $\quad \mathrm{c}-\left(\mathrm{Ti}_{0.23}, \mathrm{Al}_{0.77}\right) \mathrm{N}(111)[1-10] \mid \mathrm{w}^{-}$ $\left(\mathrm{Ti}_{0.23}, \mathrm{Al}_{0.77}\right) \mathrm{N}(0001)[11-20]$. Le $\mathrm{w}-\left(\mathrm{Ti}_{0.23}, \mathrm{Al}_{0.77}\right) \mathrm{N}$ montre une séparation de phases en domaines cohérents de taille nanométrique avec une composition chimique variable au cours de la croissance. Après recuit à haute température, les domaines de $\mathrm{w}-\left(\mathrm{Ti}_{0.23}, \mathrm{Al}_{0.77}\right) \mathrm{N}$ ont grossi mais restent plus petits que ceux du film c-(Ti $\left.{ }_{0.27}, \mathrm{Al}_{0.63}\right) \mathrm{N}$ ayant subi une décomposition spinodale. Les résultats de cette thèse revêtent une grande importance pour l'industrie des outils de coupe, ainsi que pour l'industrie de la microélectronique, car les couches ainsi développées ont des propriétés bien adaptées pour des applications en tant que barrières de diffusion.

Le but de cette étude est d'avoir une compréhension en profondeur de l'évolution de la microstructure, de la structure des défauts et des transitions de phases dans (Ti,Al)N. La première partie étudie la réponse thermique et l'évolution structurelle de films de c-(Ti,Al)N polycristallins déficitaires en azote élaborés avec différentes tensions de polarisation. Ensuite, des films de c-(Ti,Al)N ayant différentes teneurs en azote ont été soumis à un test de coupe du métal afin d'examiner leur mécanisme d'usure et leur comportement pendant l'utilisation. Cette étude vise également à déterminer l'évolution locale des contraintes et les détails de la structure des défauts lors de la décomposition spinodale en caractérisant des films monocristallins orientés (o01)- et (111) orientés ( $\mathrm{N}, \mathrm{Ti}, \mathrm{Al}$ ) de composition chimique différente.

Cette thèse contient les articles annexés montrant des résultats complets. Le papier 1 aborde l'influence des défauts ponctuels générés lors du dépôt par arc cathodique sur la stabilité de phase et le développement microstructural de films minces de $\left(\mathrm{Ti}_{1-\mathrm{x}}, \mathrm{Al}_{\mathrm{x}}\right) \mathrm{N}_{\mathrm{y}}$ déficitaires en azote. L'influence de la tension de 
polarisation sur la concentration de défauts ponctuels (par exemple autointerstitiels et anti-sites) dans les alliages c-( $\left.\mathrm{Ti}_{0.54}, \mathrm{Al}_{0.46}\right) \mathrm{N}_{0.87}$ et, par conséquent, sur leurs propriétés microstructurales et mécaniques à hautes températures ont ainsi été montrées. L'amélioration de la force motrice pour la séparation de phase à une tension de polarisation élevée de $-80 \mathrm{~V}$ a été montrée et attribuée à l'annihilation retardée des défauts ponctuels entraînant une augmentation de l'énergie interne du système. L'effet de durcissement par vieillissement des films est conservé jusqu'à $1100{ }^{\circ} \mathrm{C}$ (c'est-à-dire la température la plus élevée signalée pour les films de (Ti,Al)N en appliquant une tension de polarisation faible et en réduisant la concentration en azote du revêtement pendant le dépôt. Les résultats ouvrent des pistes de conception futures pour les revêtements de nitrure de métaux de transition et permettent de mieux comprendre l'effet des défauts ponctuels générés lors du dépôt physique en phase vapeur.

Le papier 2 présente les principaux facteurs influençant le comportement à l'usure des revêtements $\left(\mathrm{Ti}_{1-\mathrm{x}}, \mathrm{Al}_{\mathrm{x}}\right) \mathrm{N}_{\mathrm{y}}$ déficitaires en azote lors du découpage à grande vitesse d'une pièce en acier. La condition de polarisation optimale précisée dans le document 1 a été utilisée pour la synthèse de films (Ti,Al)N avec différentes teneurs en azote. Ensuite, l'interaction des lacunes en azote, de la microstructure et de la réaction chimique des revêtements c- $\left(\mathrm{Ti}_{0.52} \mathrm{Al}_{0.48}\right) \mathrm{N}_{\mathrm{y}}$ avec une concentration moyenne en $\mathrm{N}$ de $\mathrm{y}=0.92, \mathrm{y}=0.87$ et $\mathrm{y}=0.75$ a été étudiée. Le revêtement $\mathrm{y}=0.75$ contient le plus grand nombre de macroparticules et présente une microstructure non homogène après usinage contenant des phases c- $\left(\mathrm{Ti}_{0.52} \mathrm{Al}_{0.48}\right) \mathrm{N}_{\mathrm{y}}, \mathrm{Ti}_{2} \mathrm{AlN}$ (phase MAX) et des couches alternées de phases AlN et Fe-Ti à proximité des macroparticules. Dans ce cas, l'altération chimique au sein du revêtement et la présence de macroparticules ont contribué à sa relativement faible résistance à l'usure des flancs et des cratères. L'échantillon $\mathrm{y}=0.92$ présente une décomposition spinodale plus précoce en domaines riches en c-AlN et en c-TiN, par rapport aux autres échantillons. Cette structure décomposée présente des dislocations inadaptées (comme observé dans le document 3) qui ont provoqué la diffusion accélérée de Fe et de Co à partir de la pièce et du substrat à travers le revêtement, ce qui affaiblirait la structure du revêtement et le rendrait plus susceptible à l'usure. Il y a un retard dans la décomposition de l'échantillon $\mathrm{y}=0.87$, qui est causée par la présence de lacunes d'azote qui abaissent l'énergie libre du système. La survenue d'un durcissement lié au vieillissement dans l'échantillon y = $0.92 \mathrm{a}$ entraîné une résistance supérieure à l'usure des flancs parmi les échantillons, tandis que la structure dense de l'échantillon y $=0.87$ qui empêchait l'usure chimique due à la diffusion a provoqué son excellente résistance à l'usure dans les cratères. Cette étude donne un aperçu du rôle des lacunes d'azote dans la 
réaction chimique et le comportement à l'usure des revêtements de nitrure de métal de transition au cours de l'usinage.

Le papier 3 s'attache à l'étude des défauts structuraux de la phase monocristalline de c-(Tio.37, $\left.\mathrm{Al}_{0.63}\right) \mathrm{N}$ durant sa décomposition spinodale. Des couches minces hétéroépitaxiées de c-(Tio.37, $\left.\mathrm{Al}_{0,63}\right) \mathrm{N}$ ont été déposées sur des substrats de $\mathrm{MgO}$ (001) et (111) par pulvérisation cathodique magnétron. Les films monocristallins avec un haut niveau de pureté permettent de déterminer les détails de leur structure de dislocation en utilisant des techniques de diffraction et d'imagerie à haute résolution. La qualité cristalline des films monocristallins (Ti,Al)N a été examinée par DRX à haute résolution, par cartographies réciproques (RSM) et par microscopie électronique à transmission par balayage en champ sombre annulaire à grand angle (HAADFSTEM). Les mesures RSM montrent que le film recuit (c'est-à-dire ayant subit une décomposition spinodale) a une corrélation latérale inférieure, une largeur à mi-hauteur plus importante et une mosaïté supérieure par rapport au film brut de dépôt. Les images HAADF-STEM montrent que les films ainsi déposés ont une composition homogène, sans signe de ségrégation élémentaire, tandis que les films recuits se décomposent pour former des domaines cohérents riches en c-AlN et c-TiN de forme allongée selon la direction <001>. Les cartographies de déformation contenant les composantes du tenseur de contraintes (par exemple $\varepsilon_{\mathrm{xx}}, \varepsilon_{\mathrm{yy}}$ et $\varepsilon_{\mathrm{xy}}$ ) de c-(Ti,Al)N ont été présentées pour la première fois dans cette étude par analyse de phase géométrique (GPA) sur des micrographies HAADF-STEM. Les résultats révèlent que les déformations se trouvent près de l'interface des domaines ségrégés et que les domaines c-TiN hébergent plus de dislocations que les domaines c-AlN. Ceci est attribué à la forte directionnalité des liaisons chimiques covalentes de c-AlN, qui permet aux dislocations de s'agréger favorablement dans c-TiN. Les résultats indiquent que l'état de la liaison chimique et les propriétés élastiques des domaines séparés affectent la structure des défauts de (Ti,Al)N pendant la décomposition spinodale.

Le papier 4 montre pour la première fois la croissance épitaxiale du film w$\left(\mathrm{Ti}_{0.23}, \mathrm{Al}_{0.77}\right) \mathrm{N}$ (0001) sur un substrat de $\mathrm{MgO}(111)$. Le film a été développé à $700{ }^{\circ} \mathrm{C}$ en utilisant un système de pulvérisation cathodique magnétron UHV DC. Un film monocristallin de $\mathrm{c}-\left(\mathrm{Ti}_{0.23}, \mathrm{Al}_{0.77}\right) \mathrm{N}$ est d'abord développé jusqu'à une épaisseur critique (entre 10 et $30 \mathrm{~nm}$ ) en utilisant une couche tampon de TiN(111) déposée sur $\mathrm{MgO}(111)$. Au-delà de cette épaisseur, il se produit une transition de la structure cubique vers la structure wurtzite, avec une interface en zigzag entre les deux structures. L'interface présente une relation d'orientation de c-(Tio.23, $\left.\mathrm{Al}_{0.77}\right) \mathrm{N}(111)[1-10] \mid \mathrm{w}-\left(\mathrm{Ti}_{0.23}, \mathrm{Al}_{0.77}\right) \mathrm{N}(\mathrm{ooO1})[11-2 \mathrm{O}]$. La 
poursuite des dépôts a pour conséquence une décomposition progressive de la croissance épitaxique en croissance polycristalline de colonnes de wurtzite à degré de texture élevé. Les images TEM dans le plan montrent que les grains de wurtzite grossissent à mesure que le film s'épaissit. Cette étude compare également la stabilité thermique des structures épitaxiques w$\left(\mathrm{Ti}_{0.23}, \mathrm{Al}_{0.77}\right) \mathrm{N}(0001)$ et c-(Tio.37, $\left.\mathrm{Al}_{0.63}\right) \mathrm{N}(111)$. Le dépôt w-(Ti $\left.{ }_{0.23}, \mathrm{Al}_{0.77}\right) \mathrm{N}(0001)$ tel que déposé montre un regroupement de domaines cohérents de taille nanométrique tandis que $\mathrm{c}-\left(\mathrm{Ti}_{0.37}, \mathrm{Al}_{0.63}\right) \mathrm{N}(111)$ reste homogène. Après un recuit à $900{ }^{\circ} \mathrm{C}$, le film cubique a subi une décomposition spinodale pour former des domaines allongés riches en c-AlN et c-TiN selon la direction [001] (c'est-à-dire comme indiqué dans le papier 3), tandis que le film de wurtzite présente des domaines de taille légèrement supérieure à celle du film bruet d'élaboration. La structure wurtzite présente une vitesse de grossissement plus lente comparée à celle de la forme cubique, ce qui indique une plus grande stabilité thermique.

Le papier 5 étudie la croissance et la stabilité thermique de films épitaxiés de $\left(\mathrm{Ti}_{1-\mathrm{x}}, \mathrm{Al}_{\mathrm{x}}\right) \mathrm{N}_{\mathrm{y}}$ avec une teneur moyenne en azote de $\mathrm{y}=0.67,0.79$ et 0.92 déposés par pulvérisation cathodique magnétron sur des substrats de $\mathrm{MgO}$ orientés (111) et (o01) . L'épitaxie de c-( $\left.\mathrm{Ti}_{1-\mathrm{x}}, \mathrm{Al}_{\mathrm{x}}\right) \mathrm{N}_{\mathrm{y}}(111)$ sur $\mathrm{MgO}$ (111) est maintenue selon toute l'épaisseur du film. Les cartographies spatiales réciproques (RSM) de ces films montrent que la longueur de la corrélation latérale est supérieure et que la propagation de la mosaïcité est plus lente pour les films ayant une teneur en $\mathrm{N}$ plus faible. Des couches épitaxiques de c-( $\mathrm{Ti}_{1-}$ $\left.{ }_{x}, \mathrm{Al}_{\mathrm{x}}\right) \mathrm{N}_{\mathrm{y}}(\mathrm{OO1})$ ont été déposées sur $\mathrm{MgO}(\mathrm{OO1})$ pendant une certaine épaisseur (quelques nanomètres), puis une transition vers une croissance polycristalline se produit. L'épaisseur de la couche épitaxique de c-( $\left(\mathrm{Ti}_{1-\mathrm{x}}, \mathrm{Al}_{\mathrm{x}}\right) \mathrm{N}_{\mathrm{y}}(\mathrm{O01})$ augmente à mesure que la teneur en azote diminue. La meilleure qualité cristalline des films à faible teneur en azote est attribuée à la grande mobilité de surface des cations dans des conditions déficitaires en azote. Les couches épitaxiées de $\mathrm{c}-(\mathrm{Ti}, \mathrm{Al}) \mathrm{N}(111)$ et de $\mathrm{c}-(\mathrm{Ti}, \mathrm{Al}) \mathrm{N}(\mathrm{OO1})$ sont homogènes à l'état déposé, puis des domaines ségrégés apparaissent après un recuit à $950^{\circ} \mathrm{C}$. Les films c-(Ti,Al)N(111) ont des domaines plus grands que ceux de c$(\mathrm{Ti}, \mathrm{Al}) \mathrm{N}(\mathrm{OO1})$ et la taille des domaines des films de c-(Ti,Al)N orientés (oO1) et (111) augmente avec la teneur en azote. Cela indique qu'il y a un retard dans le grossissement des grains en présence de lacunes d'azote. Des caractéristiques uniques sont observées dans les films de $\left(\mathrm{Ti}_{1-x}, \mathrm{Al}_{\mathrm{x}}\right) \mathrm{N}_{\mathrm{o} .67}$, qui contiennent la plus grande quantité de lacunes d'azote. Le film de $\left(\mathrm{Ti}_{1-\mathrm{x}}, \mathrm{Al}_{\mathrm{x}}\right) \mathrm{N}_{\mathrm{o.67}}(111)$ sur $\mathrm{MgO}(111)$ cristallise dans une structure de type wurtzite avec une orientation cohérente avec $\mathrm{w}-\left(\mathrm{Ti}_{1-\mathrm{x}}, \mathrm{Al}_{\mathrm{X}}\right) \mathrm{N}_{0.67}(\mathrm{OOO1})$ dans certaines régions situées au sommet du film. Le film de $\left(\mathrm{Ti}_{1-\mathrm{x}}, \mathrm{Al}_{\mathrm{x}}\right) \mathrm{N}_{\mathrm{o.67}}(\mathrm{OO1})$ élaboré sur $\mathrm{MgO}(\mathrm{O01})$ présente une 
microstructure conique avec des domaines séparés déjà dès la synthèse des films et reste stable lorsqu'il est recuit à $950^{\circ} \mathrm{C}$. La taille de domaine de ce film augmente légèrement après le recuit à $1100{ }^{\circ} \mathrm{C}$. La vitesse de grossissement des domaines coniques est plus lente que celle des domaines de la couche épitaxiée à des températures élevées. La concentration de lacunes d'azote affecte la stabilité thermique des films minces épitaxiés $\left(\mathrm{Ti}_{1-\mathrm{x}}, \mathrm{Al}_{\mathrm{x}}\right) \mathrm{N}_{\mathrm{y}}$. 


\section{Preface}

This thesis is the summary of my doctoral studies conducted within the framework of the Erasmus Mundus Joint Doctoral Program in Material Science and Engineering (DocMASE) between October 2014 and June 2019. I worked in the research groups of Nanostructured Materials Division at the Department of Physics, Chemistry, and Biology (IFM) at Linköping University (Linköping, Sweden) and at the Elaboration et Fontionnalités de Couches Minces at the Intitut Jean Lamour (IJL) at Université de Lorraine (Nancy, France). The cathodic arc depositions were done in Seco Tools AB (Fagersta, Sweden). This work is financially supported by EU (DocMASE), the Swedish Research Council, and Vinnova (FunMat-II).

Katherine M. Calamba

Linköping, May 2019 


\section{Included papers and author's contribution}

\section{Paper 1}

Enhanced thermal stability and mechanical properties of nitrogen deficient titanium aluminum nitride $\left(\operatorname{Ti}_{0.54} \mathbf{A l}_{0.46} \mathrm{~N}_{\mathrm{y}}\right)$ thin films by tuning the applied negative bias voltage

K. Calamba, I. Schramm, M. Johansson Jõesaar, J. Ghanbaja, J. Pierson, F. Mücklich, and M. Odén

Journal of Applied Physics 122, 065301 (2017)

\section{Paper 2}

The effect of nitrogen vacancies on initial wear in arc deposited $\left(\mathrm{Ti}_{\mathrm{o} .52}, \mathrm{Al}_{\mathrm{o} .48}\right) \mathrm{N}_{\mathrm{y}},(\mathrm{y}<\mathbf{1})$ coatings during machining

K. Calamba, M. Johansson Jõesaar, S. Bruyère, J. Pierson, R. Boyd, J. Andersson, M. Odén

Surface \& Coatings Technology 358, 452-46o (2019)

\section{Paper 3}

Dislocation structure and microstrain evolution during spinodal decomposition of reactive magnetron sputtered heteroepixatial c( $\mathrm{Ti}_{\text {o.37 }}, \mathrm{Al}_{\mathrm{o.63}}$ ) N/c-TiN films grown on $\mathrm{MgO}(\mathrm{Oo1})$ and (111) substrates K. Calamba, J. Pierson, Bruyère, A. Febvrier, P. Eklund, J. Barrirero, F. Mücklich, R. Boyd, M.P. Johansson Jõesaar, and M. Odén

Journal of Applied Physics 125, 105301 (2019)

\section{Paper 4}

Growth and high temperature decomposition of epitaxial metastable wurtzite $\left(\mathbf{T i}_{1-x}, \mathbf{A l}_{\mathbf{x}}\right) \mathbf{N}(\mathbf{O O O 1})$ thin films

K. Calamba, J. Barrirero, M. Johansson Jõesaar, S. Bruyère, J. Pierson, A. Febvrier, Mücklich, R. Boyd, and M. Odén

Submitted for publication

\section{Paper 5}

Effect of vacancies on the dislocation structure and and phase stability of nitrogen deficient single crystal $\left(\mathrm{Ti}_{1-\mathrm{x}}, \mathrm{Al}_{\mathrm{x}}\right) \mathbf{N}_{\mathrm{y}}$ thin films

K. Calamba, J. Salamania, M. Johansson Jõesaar, R. Boyd, S. Bruyère, J. Pierson, M. Sortica, D. Primetzhofer, and M. Odén

In manuscript 


\section{Related but not included paper}

Adhesive-deformation relationships and mechanical properties of

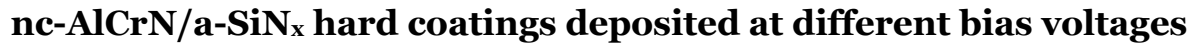

M. Haršáni, N. Ghafoor, K. Calamba, P. Zacková, M. Sahul, T. Vopát, L. Satrapinskyy, M. Čaplovičová and L. Čaplovič

Thin Solid Films 65o, 11-19 (2018)

\section{My contribution to the included papers}

I was involved in the planning and design of the experiments. I took part in the cathodic arc depositions and did all the sputter depositions. I did the majority of the sample preparations and characterizations including differential scanning calorimetry, x-ray diffractometry (theta-2theta, phi scan, gracing incidence, residual stress measurements, pole figures, and reciprocal space maps), nanoindentation, 4-point probe, crater and flank wear measurements, scanning electron microscopy, ion milling, transmission electron microscopy and geometric phase analysis. I wrote the first draft of the papers. 


\section{Acknowledgements}

I am very grateful for the valuable help and support of the following:

Magnus Odén, my supervisor in LiU.

Jean Pierson, my supervisor in UoL.

Mats Johansson Jöesaar, my supervisor in Seco Tools AB.

Collaborators. Isabella Schramm, Jeni Barrirero, Stéphanie Bruyere, Janella Salamania, Robert Boyd, Marian Haršáni, Per Eklund, Arnaud le Febvrier, Jaafar Ghanbaja, Mauricio Sortica, Daniel Primetzhofer, Franck Mücklich, and Jon Andersson.

Wei Wan, Sylvie Migot, Michelle Villamayor, Magnus Garbrecht, Fredrik Erickson, Alexandra Serban, and Davide Sangiovanni for their technical help and scientific input.

Research groups. Nanostructured Materials and Elaboration et Fontionnalités de Couches Minces.

Funding institutions. EU (DocMASE), the Swedish Research Council, and Vinnova (FunMat-II).

Friends in Linkoping University, University of Lorraine, University of the Philippines, TCSHS, Östergötland, and Värmland, especially Michelle, Martin, Sebastian, Jay-el, Klein, Janella, Rommel, Carl, Rafael, Tyna, Natalia, Yan, Hongling, Lianlian, Larry, Divina, Joyme, Vanessa, Karen, and Marjory.

Brethren in Lakas Angkan Inc. and Koinonia International, especially my bible study network, cell group (Desiree, Hajdi, Linda, Jovita, Dolores, and Sarah), Eliza, Esther ladies, Ate Ellen, Kuya Elson, Del Rosario family, and Rubio family.

Mark, Ate Luz, and my family (Lovenessa, Aristotle, Antonina, and Ernesto).

All glory to him who alone is God, our Savior through Jesus Christ our Lord. All glory, majesty, power, and authority are his before all time, and in the present, and beyond all time - Jude 1:25. 
Xviii 


\section{Contents}

1. Introduction ............................................................................. 1

2. (Ti,Al)N hard coating …………............................................... 3

2.1 Phase Stability ……............................................................ 3

2.2 Diffusional transformations …………………..................... 5

2.2.1 Spinodal Decomposition ............................................ 5

2.2.2 Coarsening .................................................................... 6

2.3 Crystal Structure ........................................................ 7

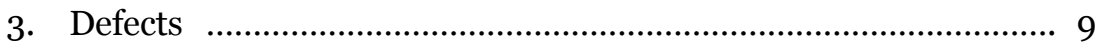

3.1 Point Defects .................................................................... 9

3.2 Dislocation Structure ....................................................... 12

4. Coating Deposition …………................................................. 15

4.1 Cathodic Arc Deposition …….................................................. 15

4.2 DC Magnetron Sputtering ...................................................... 17

4.2.1 Growth Conditions …………………........................ 18

4.2.2 Effect of Substrate ………….................................... 19

5. Metal Cutting ............................................................................ 23

5.1 Wear Mechanism ................................................................. 23

5.2 Effect of Microstructure and Chemical Interaction ................ 25

6. Characterization Techniques ……………….............................. 29

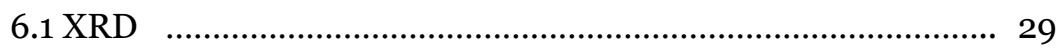

6.1.1 Residual Stress ........................................................ 29

6.1.2 Reciprocal Space Maps ................................................ 30

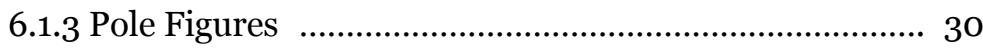

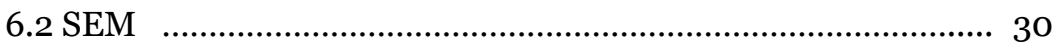

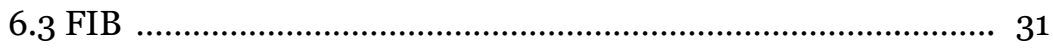

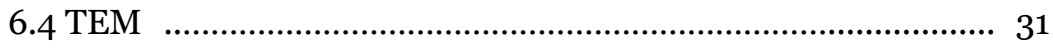

6.5 GPA Analysis ................................................................... 31

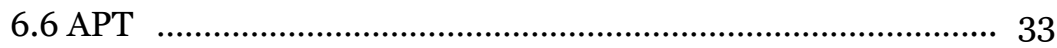

6.7 Nanoindentation ................................................................ 34

6.8 Thermal Analysis .............................................................. 35

6.9 Ion Beam Analysis ............................................................. 35

7. Summary of papers and contribution to field .............................. 37

7.1 Paper 1 .......................................................................... 37

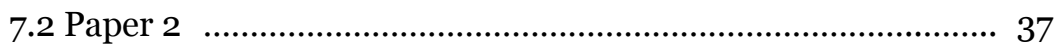

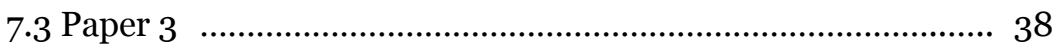

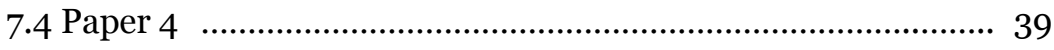

7.5 Paper 5 ……….......................................................... 39 


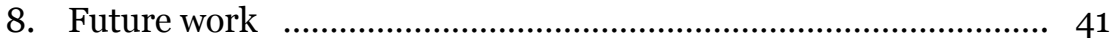

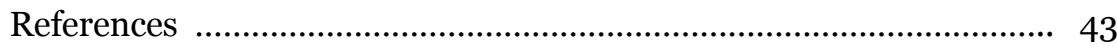




\section{Acronyms and symbols}

$\begin{array}{ll}\text { 1D } & \text { one-dimensional } \\ \text { 3D } & \text { three-dimensional } \\ \text { APT } & \text { atom probe tomography } \\ \text { c- } & \text { cubic crystal structure } \\ \text { DC } & \text { direct current } \\ \text { DSC } & \text { differential scanning calorimetry } \\ E & \text { internal energy } \\ \text { EDX } & \text { energy dispersive x-ray spectroscopy } \\ \text { EFTEM } & \text { energy filtered transmission electron microscopy } \\ \text { ERDA } & \text { elastic recoil detection } \\ \text { FFT } & \text { Fast Fourier transform } \\ \text { FIB } & \text { Focused ion beam } \\ \text { G } & \text { Gibb's free energy } \\ \text { GPA } & \text { geometric phase analysis } \\ H & \text { enthalpy } \\ \text { HAADF } & \text { high-angle annular dark field } \\ \text { HR } & \text { high resolution } \\ P & \text { pressure } \\ \text { PVD } & \text { physical vapor deposition } \\ \text { RBS } & \text { Rutherford backscattering spectrometry } \\ \text { RSM } & \text { reciprocal space maps } \\ S & \text { entropy } \\ \text { SAED } & \text { selected area electron diffraction } \\ \text { STEM } & \text { scanning transmission electron micrography } \\ \text { TEM } & \text { transmission electron microscopy } \\ T & \text { temperature } \\ \text { TOF } & \text { Time-of-flight } \\ \text { TMN } & \text { transition metal nitride } \\ \text { W- } & \text { wurtzite crystal structure } \\ V & \text { volume } \\ \text { XRD } & \text { X-ray diffractometry } \\ & \end{array}$


xxii 


\section{Introduction}

A majority of mechanical parts used in industries such as aerospace and power generation are used under severe working conditions. Steel and titanium or their alloys are the commonly utilized materials for such application because of their properties that are suitable for such conditions (e.g. high specific strength at high temperature, resistance to corrosion, and chemical inertness) [1, 2]. One of the outstanding challenges is to machine these materials into a specific geometry. Thus, it is necessary to have cutting tool materials that have high mechanical strength and have high resistance to the heat generated during the machining process. Coating deposition on carbide inserts has been developed for cutting applications because it results in higher wear and heat resistance than uncoated inserts and it improves the machining accuracy and lifetime of the mechanical parts [3-5].

Among the coating materials, titanium aluminum nitride (Ti,Al)N is a widely utilized material system because of its superior oxidation resistance and ability to age hardening $[6,7]$. The latter attribute is due to the spinodal decomposition of metastable (Ti,Al)N into iso-structurally coherent c-TiN and c-AlN domains at elevated temperatures [8, 9]. Further annealing results in the transformation of c-AlN to its most stable form w-AlN, which is detrimental to the high temperature hardness of the coating [8]. Delaying the phase transformation of AlN is therefore necessary to enhance the thermal stability and mechanical properties of (Ti,Al)N.

The thermodynamics of a ternary alloy is mainly influenced by its chemical composition and point defect concentrations [10-12], besides external factors such as temperature and pressure. Investigating the materials related factors could lead to the determination of the optimum conditions for synthesizing hard coatings. $A b$ initio calculations recently showed that nitrogen vacancies have significant effect on the thermal stability of $c-(\mathrm{Ti}, \mathrm{Al}) \mathrm{N}$ [13]. Following reports have confirmed through experiments that $\mathrm{N}$ vacancies suppress the driving force for phase transformation and causes shifts of the c-AlN to w-AlN transformation to higher temperatures [14, 15].

In this study, the aim was to have an in-depth understanding of the microstructural evolution, defect structure and phase transitions in (Ti,Al)N. The first part investigates the thermal response and structural evolution of nitrogen deficient poly-crystalline $c$-(Ti,Al)N films with different applied negative bias voltage. Then, $c-(\mathrm{Ti}, \mathrm{Al}) \mathrm{N}$ films with different $\mathrm{N}$ contents were 
subjected to metal cutting test to examine their wear mechanism and behavior during service. This study also aims to determine the local strain evolution and the details of the defect structure during spinodal decomposition by characterizing (oo1)- and (111)- oriented mono-crystalline (Ti,Al)N films with different chemical composition.

In chapter 2, the thermodynamics and kinetics of the phase transformation of (Ti,Al)N material system are presented. The role of point and line defects on the phase stability of (Ti,Al)N is elaborated in Chapter 3. Chapter 4 describes the physical vapor deposition techniques used to fabricate poly- and monocrystalline films with different stoichiometry. The effect of the microstructural and chemical changes of the coatings after subjecting to metal cutting on the wear behavior are shown in Chapter 5. Chapter 6 describes the characterization techniques used in this thesis. A summary of the appended papers and the future work are presented in Chapter 7 and Chapter 8, respectively. The last part of the thesis contains the appended papers showing comprehensive results. 


\section{2. (Ti,Al)N hard coating}

Thin ceramic coatings are used in cutting industries because they significantly improves the lifetime of cutting tools. Titanium nitride (TiN) is one of the first hard coatings utilized due to its high hardness, corrosion resistance, and aesthetic appearance (i.e. golden color). When Ti atoms in the metal sublattice of TiN are randomly replaced with $\mathrm{Al}$, the $\left(\mathrm{Ti}_{1-\mathrm{x}}, \mathrm{Al}_{\mathrm{x}}\right) \mathrm{N}$ material system is formed. In cutting tool operations, this material offers numerous advantages as compared to TiN in terms of oxidation resistance and high temperature hardness $[6,16]$.

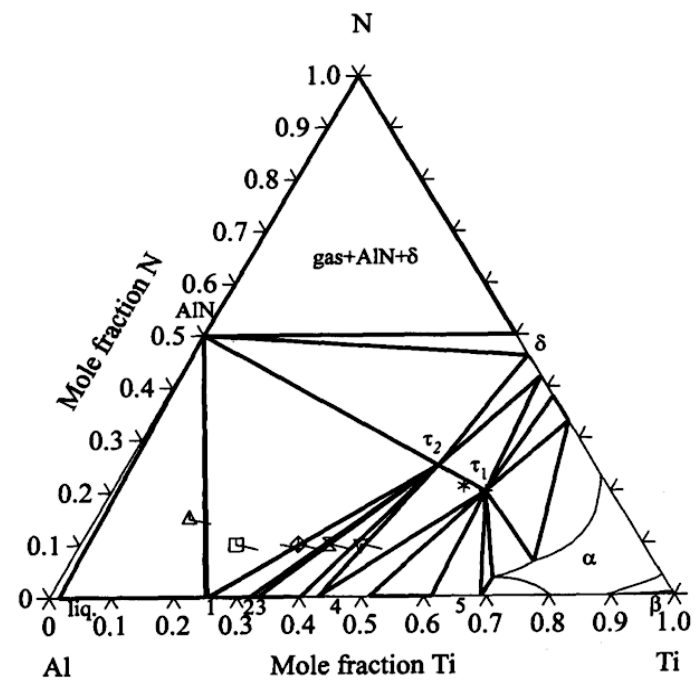

Fig 2.1. Phase diagram of Ti-Al-N system at $1000{ }^{\circ} \mathrm{C} .\left(\tau_{1}: \mathrm{Ti}_{3} \mathrm{AlN}, \tau_{2}: \mathrm{Ti}_{2} \mathrm{AlN}, \delta: \mathrm{TiN}\right.$, 1:TiAl $3,2: \mathrm{Ti}_{5} \mathrm{Al}_{11}, 3: \mathrm{TiAl}_{2}, 4: \gamma \mathrm{TiAl},{ }_{5}: \alpha \mathrm{Ti}_{3} \mathrm{Al}$ ), reprinted with permission [17].

\subsection{Phase Stability}

The ternary phase diagram at $1000{ }^{\circ} \mathrm{C}$ of Ti-Al-N system is shown in Figure 2.1. In this material system, the $\mathrm{Ti}_{3} \mathrm{AlN}$ and $\mathrm{Ti}_{2} \mathrm{AlN}$ phases are the only stable ternary compounds. The widely utilized $\left(\mathrm{Ti}_{1-\mathrm{x}}, \mathrm{Al}_{\mathrm{x}}\right) \mathrm{N}_{\mathrm{y}}$ is a metastable solid solution, which can be synthesized using thin film deposition techniques. Plasma based physical vapor deposition techniques (e.g. cathodic arc deposition and magnetron sputtering) enables the growth of metastable and non-equilibrium phases because of its low substrate temperature, which 
quench a homogeneous solution into the miscibility gap [7, 18]. The coating deposition of $\left(\mathrm{Ti}_{1-\mathrm{x}}, \mathrm{Al}_{\mathrm{x}}\right) \mathrm{N}$ is further discussed in Chapter 4.

The thermodynamic stability of $\left(\mathrm{Ti}_{1-\mathrm{x}}, \mathrm{Al} \mathrm{l}_{\mathrm{x}}\right) \mathrm{N}$ solid solution can be described by its Gibb's free energy (G), which is a function of composition and temperature. The free energy of every system is given by:

$$
G=E+P V-T S=H-T S
$$

where $E$ is the internal energy, $H$ is the enthalpy, and $S$ is the entropy of the system. The thermodynamic variables, $P, V$, and $T$ are the pressure, volume, and temperature, respectively. From the Gibb's free energy vs. composition diagram at constant $P$ and $T$, the region where the alloy is stable can be determined by constructing a common tangent of the free energy curve of each phase.

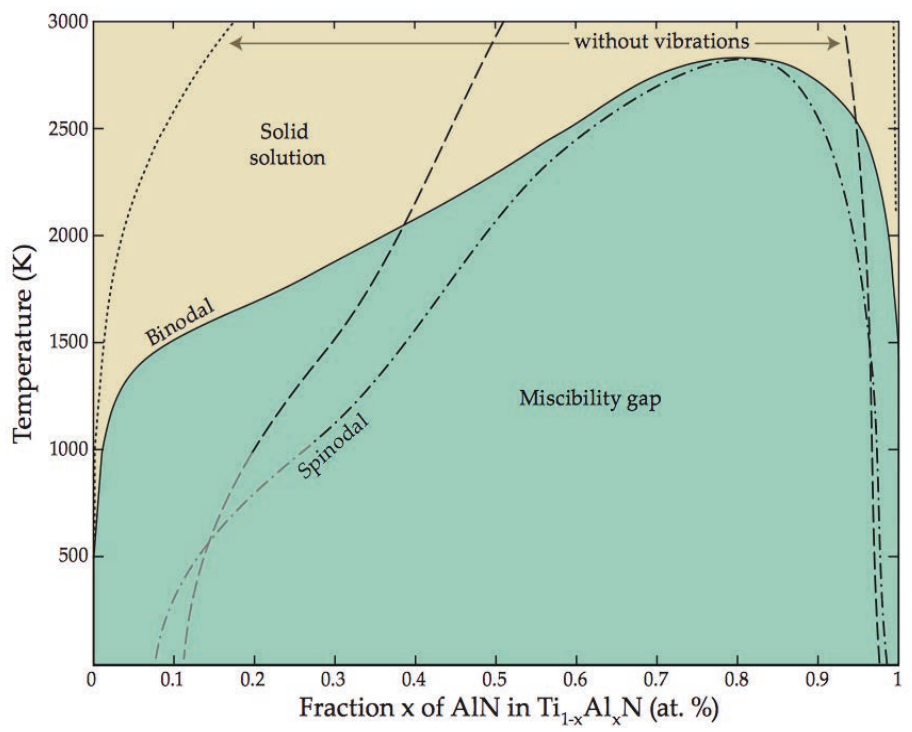

Figure 2.2. The calculated phase diagram of $\left(\mathrm{Ti}_{1-\mathrm{x}}, \mathrm{Al}_{\mathrm{x}}\right) \mathrm{N}$, reprinted with permission [19].

The calculated quasi-binary TiN-AlN phase diagram for $\left(\mathrm{Ti}_{1-\mathrm{x}}, \mathrm{Al}_{\mathrm{x}}\right) \mathrm{N}$ (Figure 2.2) shows a miscibility gap for wide range of $x$ composition, which contains two distinct regions (i.e. spinodal and binodal). Inside the miscibility gap, it is favorable for phase separation to occur. In the spinodal region, the metastable $\mathrm{c}-\left(\mathrm{Ti}_{1-\mathrm{x}}, \mathrm{Al}_{\mathrm{x}}\right) \mathrm{N}$ decompose spontaneously into isostructural and coherent $\mathrm{c}-\mathrm{TiN}-$ and c-AlN- rich domains, while in the binodal region, the domains are formed through nucleation and growth. The alloy is within the spinodal region if the 
second concentration derivative of the Gibb's free energy is negative, while it is in the binodal region if the second derivative is positive. The phase diagram also shows that when configurational and vibrational entropy are included, the maximum of the miscibility gap is lowered to $2860 \mathrm{~K}$ and the solubility of AlN in TiN is increased. Outside the miscibility gap, the solid solution of c-( $\mathrm{Ti}_{1-}$ $\left.{ }_{x} \mathrm{Al}_{\mathrm{x}}\right) \mathrm{N}$ system remains homogeneous at equilibrium. The asymmetric shape of the miscibility gap is due to the electronic structure mismatch between TiN and AlN [20]. The miscibility gap is skewed right, indicating that the there is a higher driving force for segregation of $\left(\mathrm{Ti}_{1-\mathrm{x}}, \mathrm{Al}_{\mathrm{x}}\right) \mathrm{N}$ with a high $\mathrm{Al}$ content [19]. In addition, the phase stability of $\left(\mathrm{Ti}_{1-\mathrm{x}}, \mathrm{Al}_{\mathrm{x}}\right) \mathrm{N}$ is also influenced by pressure [21-23]. These studies have shown that hydrostatic compression increases the tendency for spinodal decomposition and suppresses the formation of w-AlN phase.

\subsection{Diffusional Transformations}

The minimization of overall Gibb's free energy is the driving force for phase transformations [24]. Typical mechanisms for the transformation of $\left(\mathrm{Ti}_{1-\mathrm{x}}, \mathrm{Al}_{\mathrm{x}}\right) \mathrm{N}$ alloys are spinodal decomposition and nucleation and growth $[8$, 10]. Up-hill diffusion occurs during spinodal decomposition while down-hill diffusion occurs during nucleation and growth [24]. Phase transformation occurs in $\left(\mathrm{Ti}_{1-\mathrm{x}}, \mathrm{Al}_{\mathrm{x}}\right) \mathrm{N}$ alloys when subjected to high temperature because it enables diffusional processes to occur. The diffusion of atoms is the most fundamental process that occurs during such transformation because it results to a decrease in free energy of the system [25].

\subsubsection{Spinodal decomposition}

Spinodal decomposition is a process in which an alloy decomposes into two phases without a nucleation barrier [26]. The phase transformation is determined solely by diffusion since there is no thermodynamic barrier to the reaction. In a spinodal region, the alloy is unstable with respect to small compositional fluctuations [27]. The concentration gradient causes up-hill diffusion, in which atoms move towards regions already enriched of that atom [28].

At high temperature conditions, the $\mathrm{c}-\left(\mathrm{Ti}_{1-\mathrm{x}}, \mathrm{Al} \mathrm{x}\right) \mathrm{N}$ system undergoes spinodal decomposition until a metastable state is reached, wherein nanometer-sized domains are formed [29]. This process has been experimentally verified by in- 
situ high temperature synchrotron X-ray diffraction studies as a function of time and temperature, shown in Figure 2.3 [30]. As the temperature is increased, broadening of the $\mathrm{c}-\left(\mathrm{Ti}_{1-\mathrm{x}}, \mathrm{Al}_{\mathrm{x}}\right) \mathrm{N}$ peaks occur (marked) indicating a gradual segregation of $\mathrm{c}-\left(\mathrm{Ti}_{1-\mathrm{x}}, \mathrm{Al}_{\mathrm{x}}\right) \mathrm{N}$ into coherent $\mathrm{c}-\mathrm{TiN}$ and c-AlN- rich domains. At a certain temperature, distinct diffraction peaks of metastable cAlN and c-TiN are observed. The separation of these domains occurs during decomposition because such process leads to a decrease in free energy. Due to different lattice constant, the formation of coherent c-TiN and c-AlN domains in a spinodally-decomposed state causes the well-known age hardening of c$\left(\mathrm{Ti}_{1-\mathrm{x}}, \mathrm{Al}_{\mathrm{x}}\right) \mathrm{N}[8,31,32]$. The coherency strains and the elastic stiffness differences of the domains obstruct dislocation motion thus the hardness of this alloy increases [33-35].

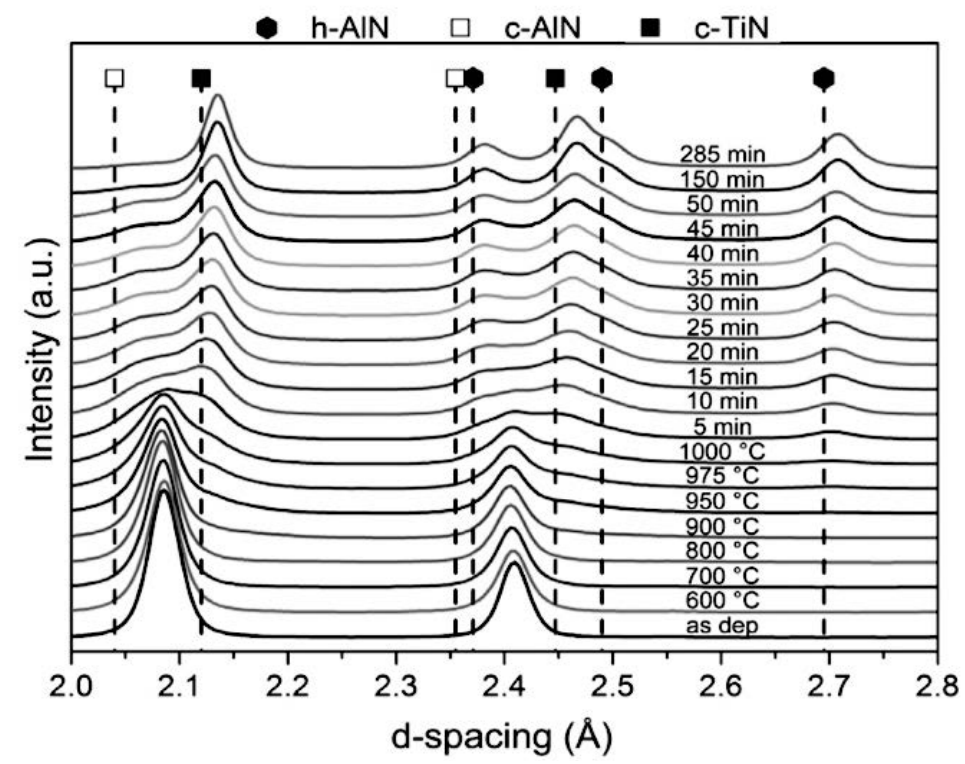

Figure 2.3. In-situ XRD of $\left(\mathrm{Ti}_{0.36}, \mathrm{Al}_{0.64}\right) \mathrm{N}$ at different temperature and different isothermal annealing time held at $1000{ }^{\circ} \mathrm{C}$, reprinted with permission [30].

\subsubsection{Coarsening}

The decomposition pathway of c-( $\left.\mathrm{Ti}_{1-\mathrm{x}}, \mathrm{Al} \mathrm{l}_{\mathrm{x}}\right) \mathrm{N}$ is given by the following [36]:

$$
\text { c-(Ti,Al)N } \rightarrow \text { c-TiN }+ \text { c-AlN } \rightarrow \text { c-TiN + w-AlN }
$$


The first stage is governed by spinodal decomposition as discussed in the previous section. If the thermal energy is further increased (i.e. enough to overcome the free energy barrier), the metastable c-AlN transforms to its equilibrium phase w-AlN [30]. It is energetically favorable for domains to coarsen because such process minimizes the free energy of the system. As the precipitates continue to grow, the coherency between the domains is lost [8]. In addition, accompanying the onset of w-AlN, the hardness significantly drops because of the large volume mismatch of the domains that enhance the tendency of dislocation movements [10].

\subsection{Crystal Structure}

The crystal structure of transition metal nitrides (TMN) is primarily determined by the number of sp valence electrons per atom (e/a) in the system $[7,8]$ The most common crystal structures of TMN are cubic B1, hexagonal $\mathrm{B}_{\mathrm{k}}$, and wurtzite B4 structures [11]. For most TMN, a change from cubic B1 to wurtzite $\mathrm{B} 4$ is observed as the e/a ratio decreases [11, 37]. The crystal structure can also be stabilized to a different phase (such as from cubic B1 to wurtzite B4) under high pressure [38, 39] or by using a substrate with a similar lattice parameter [40].

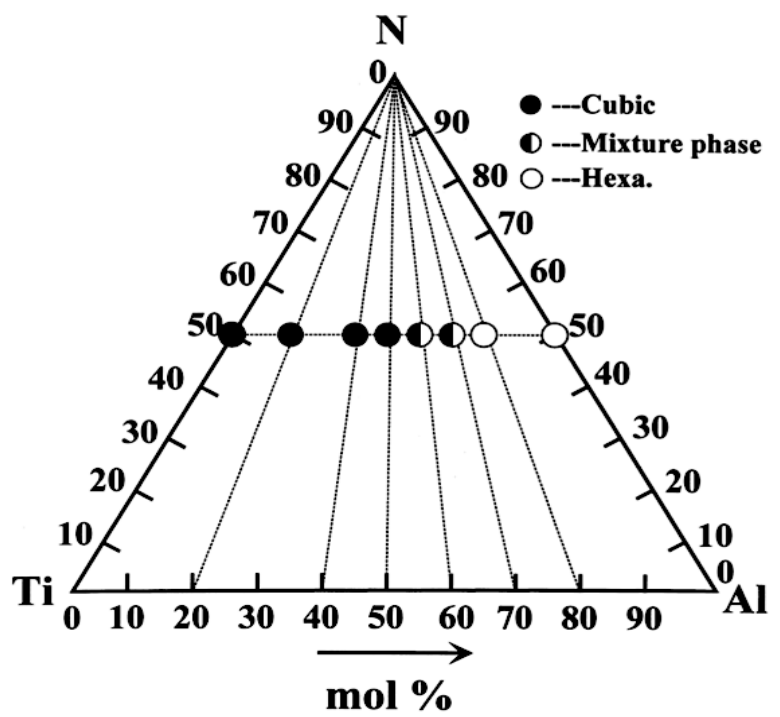

Figure 2.4. Crystal structures in the $\left(\mathrm{Ti}_{1-\mathrm{x}}, \mathrm{Al} \mathrm{A}_{\mathrm{x}}\right) \mathrm{N}$ material system, reprinted with permission [41]. 
The $\left(\mathrm{Ti}_{1-\mathrm{x}}, \mathrm{Al}_{\mathrm{x}}\right) \mathrm{N}$ system has two phases (cubic $\mathrm{B} 1$ and wurtzite $\mathrm{B} 4$ crystal structures), which is highly dependent on $\mathrm{Al}$ composition (Figure 2.4). A study has shown that film thickness also influences the crystal structure of $\left(\mathrm{Ti}_{0.38}, \mathrm{Al}_{\text {o.62 }}\right.$ ) N, wherein a transition from cubic B1 to wurtzite $\mathrm{B} 4$ is observed for a critical thickness of about $3 \mu \mathrm{m}$ [42]. Majority of the researches on $\left(\mathrm{Ti}_{1-\mathrm{x}}, \mathrm{Al}_{\mathrm{x}}\right) \mathrm{N}$ are focused on its cubic $\mathrm{B} 1$ structure because of the outstanding high temperature mechanical behavior. It is also important to investigate its wurtzite B4 structure because other properties such heat conductivity, electrical resistivity and optical reflectance are correlated with structural changes [43, 44].

In Paper 4, epitaxial growth of $\left(\mathrm{Ti}_{1-\mathrm{x}}, \mathrm{Al}_{\mathrm{x}}\right) \mathrm{N}$ films with $\mathrm{Al}$ content of $\mathrm{x}=0.63$ and $\mathrm{x}=0.77$ has been investigated [45]. $\left(\mathrm{Ti}_{0.27}, \mathrm{Al}_{0.63}\right) \mathrm{N}(111)$ film has pure cubic $\mathrm{B} 1$ structure while $\left(\mathrm{Ti}_{0.23}, \mathrm{Al}_{0.77}\right) \mathrm{N}$ film contains thin cubic $\left(\mathrm{Ti}_{0.27}, \mathrm{Al}_{0.63}\right) \mathrm{N}(111)$ in the first atomic layers due to epitaxial stabilization then a transition to epitaxial $\quad\left(\mathrm{Ti}_{0.23}, \mathrm{Al}_{0.77}\right) \mathrm{N}(0001)$ with coherent interface occurs. The microstructure, thermal stability, and functional properties of wurtzite and cubic structures of $\left(\mathrm{Ti}_{1-x}, \mathrm{Al}_{\mathrm{x}}\right) \mathrm{N}$ are further discussed in this paper. 


\section{Defects}

Transition metal nitrides (TMN) are widely investigated because they have remarkable properties such as high mechanical strength, good electrical conductivity, and high melting points $[11,46]$. The defect structure of TMN is also among its distinctive properties because the presence of vacancies and interstitials significantly affects its mechanical, electrical, and thermodynamic characteristics [11]. The $(\mathrm{Ti}, \mathrm{Al}) \mathrm{N}$ system is among these metal nitrides that has been utilized in wide range of applications [3, 6, 47]. However, there are only few reports that investigate on its defect structure [48, 49]. In this section, the emphasis is on the role of point and line defects in engineering (Ti,Al)N films with improved properties.

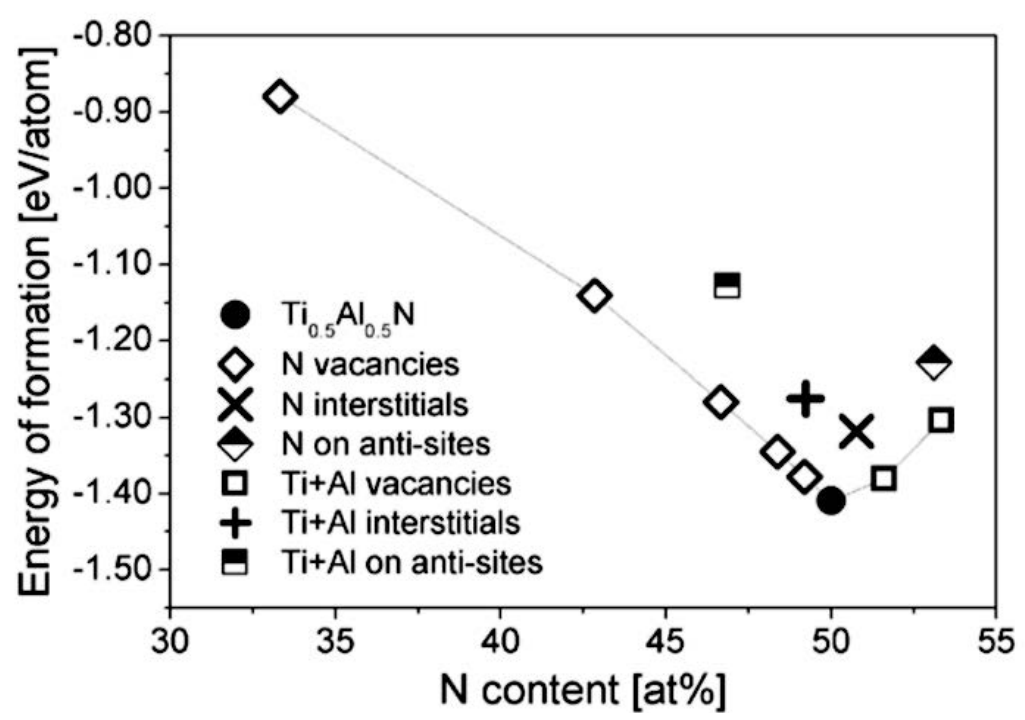

Figure 3.1 Energy of formation of $\left(\mathrm{Ti}_{0.5}, \mathrm{Al}_{0.5}\right) \mathrm{N}_{\mathrm{y}}$ for different point defects, reprinted with permission [50].

\subsection{Point Defects}

The first theoretical study on the effect of point defects on the phase stability of (Ti,Al)N system is done by Alling et al. [13], which showed that nitrogen vacancies in $c-\left(\mathrm{Ti}_{1-\mathrm{x}}, \mathrm{Al}_{\mathrm{x}}\right) \mathrm{N}_{1-\mathrm{y}}(\mathrm{O} \leq \mathrm{x}, \mathrm{y} \leq 1)$ influence the energetically preferred decomposition pattern in the $\mathrm{x}-\mathrm{y}$ composition space. to Baben et al. [50] further investigated the induced changes of $\mathrm{N}$ concentration in $\mathrm{c}-\left(\mathrm{Ti}_{\mathrm{o} .5}, \mathrm{Al}_{\mathrm{o} .5}\right) \mathrm{N}_{\mathrm{y}}$ 
using $a b$ initio calculations. Figure 3.1 shows that for $\mathrm{y}<1$, the energy of formation of $\mathrm{N}$ vacancies is smaller than those of $\mathrm{Ti}$ and $\mathrm{Al}$ interstitials, $\mathrm{Ti}$ and $\mathrm{Al}$ vacancies, and on anti-sites (i.e. occupation of metal ions or atoms on the lattice sites of nitrogen and nitrogen on the metal lattice sites). For $y>1$, the energy of formation of $\mathrm{Ti}$ and $\mathrm{Al}$ vacancies is the smallest among the point defects. This indicates that $\mathrm{N}$ vacancies are stable in sub-stoichiometric ( $\mathrm{Ti}_{1-}$ $\left.\mathrm{x}, \mathrm{Al}_{\mathrm{x}}\right) \mathrm{N}_{\mathrm{y}}$ films while metal vacancies are stable in over-stoichiometric films.
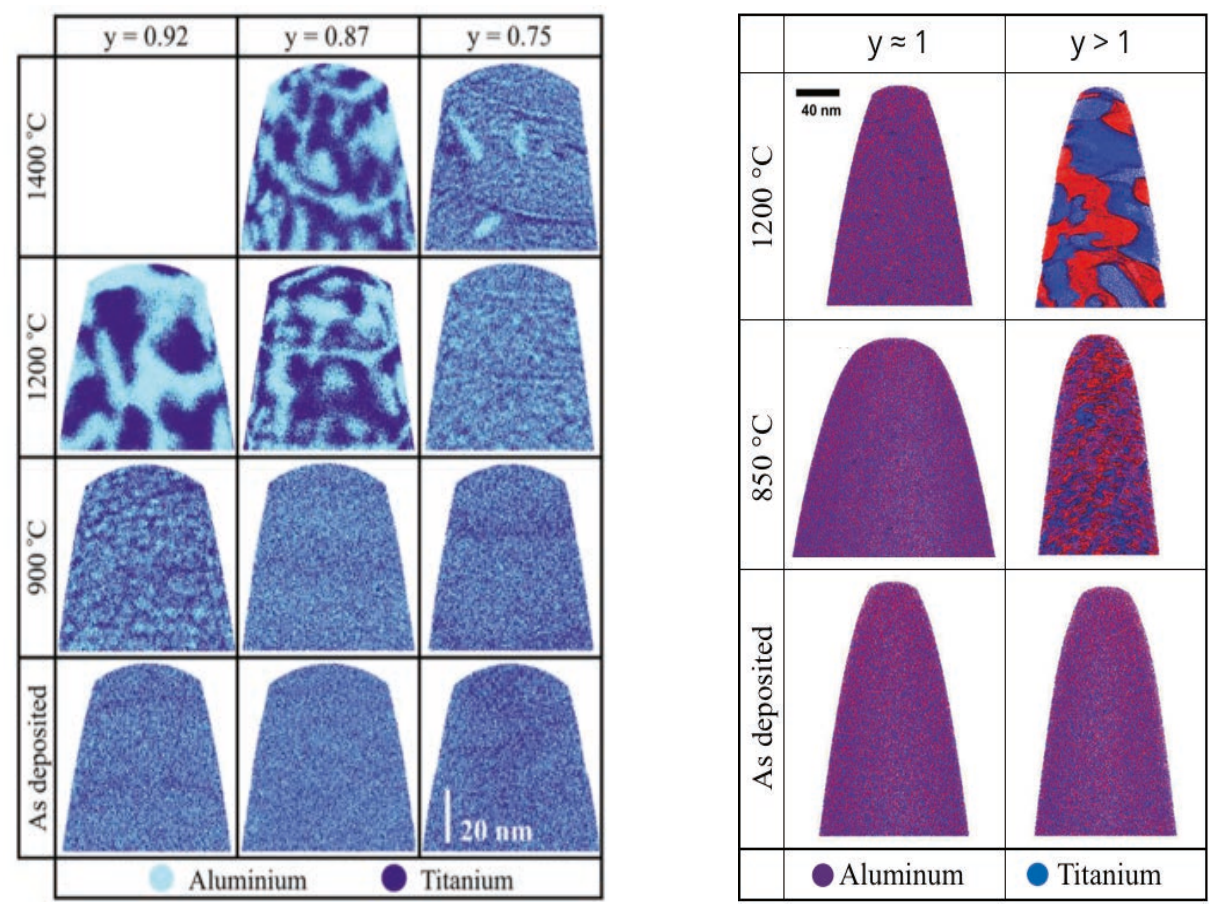

Figure 3.2. $3 \mathrm{D}$ atom probe tomography (APT) reconstructions of (left) ( $\left.\mathrm{Ti}_{0.52}, \mathrm{Al}_{0.48}\right) \mathrm{N}$ with $\mathrm{y}<1[14]$ and (right) $\left(\mathrm{Ti}_{0.5}, \mathrm{Al}_{\mathrm{O} .5}\right) \mathrm{N}$ with $\mathrm{y} \geq 1$ [51] in the as-deposited state and after annealing, reprinted with permission.

The effects of $\mathrm{N}$ concentration on the structural evolution of $\left(\mathrm{Ti}_{1-\mathrm{x}}, \mathrm{Al}_{\mathrm{x}}\right) \mathrm{N}_{\mathrm{y}}$ films after annealing were recently confirmed by $3 \mathrm{D}$ atom probe tomography (APT) $[14,51]$. Schramm et al. [14] has shown that the presence of $\mathrm{N}$ vacancies in $\left(\mathrm{Ti}_{0.52}, \mathrm{Al}_{0.48}\right) \mathrm{N}(\mathrm{y}<1)$ coatings enhance its thermal stability because the detrimental w-AlN phase evolution occurs at higher temperatures. By APT, it is clearly demonstrated that the $\mathrm{Ti}$ and $\mathrm{Al}$ domains of the close-to-stoichiometric samples have started to segregate at $900{ }^{\circ} \mathrm{C}$ while the segregation of the substoichiometric at $1200{ }^{\circ} \mathrm{C}$ (Figure 3.2a). Baben et. al [51] has shown an unprecedented thermal stability of $\left(\mathrm{Ti}_{0.5}, \mathrm{Al}_{0.5}\right) \mathrm{N}_{\mathrm{y}}$ thin films by tuning the nitrogen-to-metal ratio of the film (Figure 3.2b). The metal vacancies in the 
over-stoichiometric sample $(y \geq 1)$ enhance decomposition since there is no energy needed for vacancy formation on the metal sub-lattice but only the activation energy for changing atomic position for the diffusion processes to occur. These studies suggest that point defect engineering as a route for synthesizing $\left(\mathrm{Ti}_{1-\mathrm{x}}, \mathrm{Al}_{\mathrm{x}}\right) \mathrm{N}_{\mathrm{y}}$ coatings with enhanced properties.

The synthesis method used also affects the material defect structure. Oettel et al. [52] reported that physical vapor deposition techniques (e.g. cathodic arc evaporation) introduce point defects such as interstitials, vacancies, and antisites in (Ti,Al)N films. These defects have characteristic activation energies for diffusion and thus have different thermal stabilities [53]. One of the deposition parameters that cause the generation of such point defects is the substrate bias voltage. In Paper 1, the effect of bias voltage on the residual stress and thermal stability of nitrogen deficient $\left(\mathrm{Ti}_{0.54}, \mathrm{Al}_{0.46}\right) \mathrm{N}_{0.87}$ films was examined [54]. The film grown with an applied bias of $-80 \mathrm{~V}$ had the highest compressive residual stress. For (Ti,Al)N system, residual stresses are mainly caused by $\mathrm{N}$ interstitials and anti-sites [52].

During cathodic arc deposition, the metal ion energy of, e.g., $\mathrm{Ti}^{2+}, \mathrm{Ti}^{+}, \mathrm{Al}^{+}$ions can be more than hundred electron volts, depending on the applied substrate bias [52]. These metal ions have sufficient energies to cause defects on the growing film, e.g. by knocking-off nitrogen atoms near the surface into irregular lattice sites (i.e. interstitial and metal lattice sites) and then by replacing these nitrogen sites. The incorporation of the metal ions into the nitrogen sites and the presence of the nitrogen interstitials within the crystal cause compressive stress in the film. Applying high bias voltage increases the strain energy stored in the system and results to lattice strain formation in the crystallites and at the interfaces [55]. These factors contribute to an increase in internal energy of the system and consequently enhance the onset of decomposition for highly biased samples [54].

The enhanced phase stability in nitrogen deficient ( $\left.\mathrm{Ti}_{0.54}, \mathrm{Al}_{0.46}\right) \mathrm{N}_{0.87}$ coatings, obtained by tuning the applied bias voltage results in optimal mechanical behavior. Paper 1 shows that the age hardening of low biased (Tio.54, $\left.\mathrm{Al}_{0.46}\right)_{\mathrm{N}} \mathrm{N}_{0.87}$ films is retained until $1100{ }^{\circ} \mathrm{C}$, the highest temperature reported for $\left(\mathrm{Ti}_{1}\right.$ $\left.\mathrm{x}, \mathrm{Al}_{\mathrm{x}}\right) \mathrm{N}_{\mathrm{y}}$ coatings. The wear behavior of these films with different applied bias voltages is shown in Chapter 6. In Paper 2, the wear mechanism of films with different nitrogen concentration and fixed bias voltage of $-55 \mathrm{~V}$ (i.e. the optimum condition) was reported. 


\subsection{Dislocation structure}

In addition to point defects, the presence of dislocations, interfaces and grain boundaries also affect the phase transformation of TMN thin films. This is because the diffusivity of atoms is enhanced and the equilibrium conditions of a system are influenced in the vicinity of these defects [26]. Theoretical studies used to describe the thermodynamic energies involved in phase separation of (Ti,Al)N system are based on Cahn-Hilliard equation [27], which describes a concentration dependent mobility. Results show that spinodal decomposition of c-(Ti,Al)N is affected by the anisotropic elastic properties of c-AlN and cTiN- rich domains because they generate strain and associated strain energy $[34,35,56]$. In these studies, the strain effects generated by dislocations or other defects were ignored.

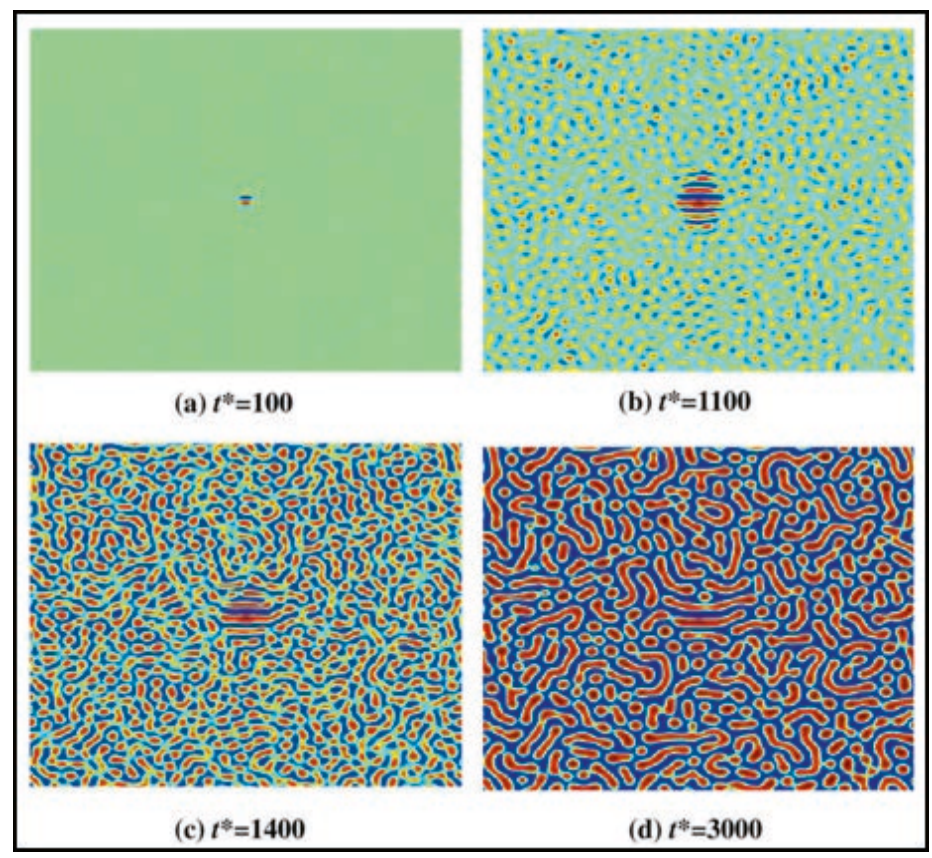

Figure 3.3. Phase separation with an edge dislocation in $\mathrm{Fe}-\mathrm{Cr}$ alloy, reprinted with permission [57].

Phase-field modelling of spinodal decomposition in alloys have recently accounted the formation and dynamics of dislocation [57-59]. Figure 3.3 shows the model result of the spinodal decomposition process for an alloy with an edge dislocation. The simulations illustrate that phase separation is faster near a dislocation, enhanced by its dislocation stress field [57]. This field enables 
the phase separation process even without initial compositional fluctuation [57].
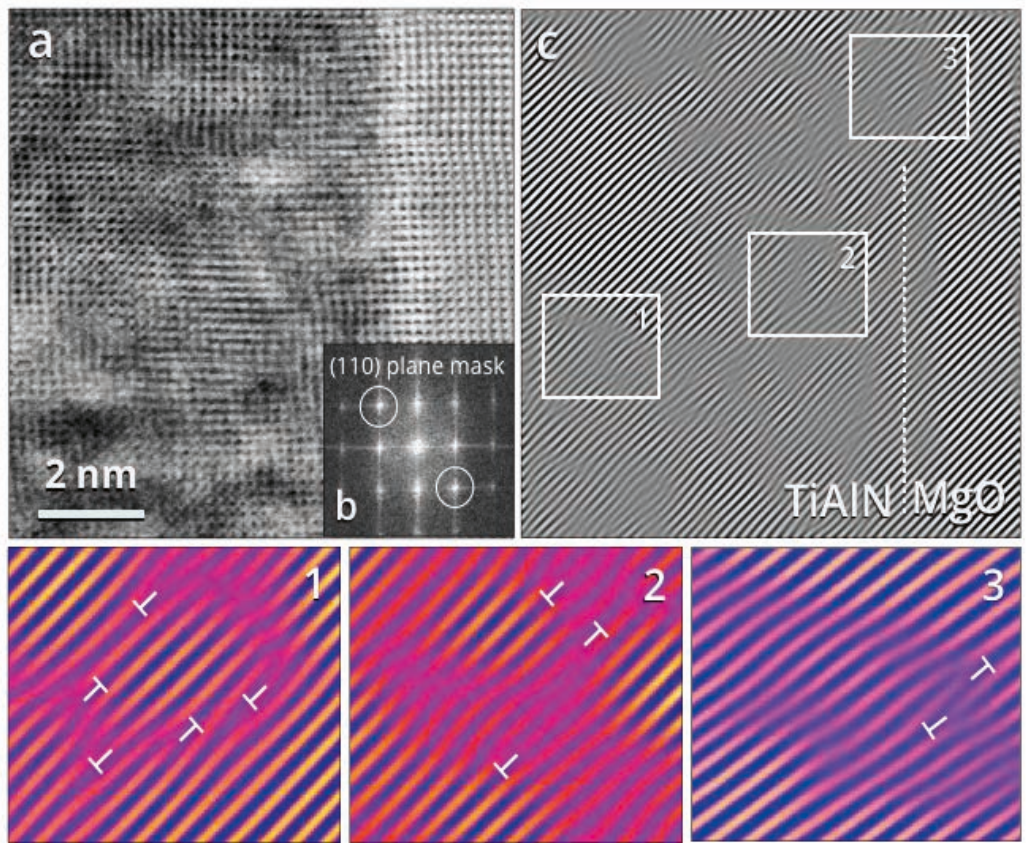

Figure 3.4. (a) High-resolution STEM cross section and (b) FFT of $\left(\mathrm{Ti}_{0.6}, \mathrm{Al}_{0.4}\right) \mathrm{N}$ on $\mathrm{MgO}(100)$. (c) A reconstructed image of the masked FFT image (marked in (b)) through inverse FFT algorithm keeping only the contribution of (110) and (1-10) planes. The insets 1, 2, and 3 are zoom on crystal defects.

In $\mathrm{Ti}_{1-\mathrm{x}} \mathrm{Al}_{\mathrm{x}} \mathrm{N}_{\mathrm{y}}$ thin films, it is likely that dislocations are generated during the deposition process that could influence the spinodal decomposition at elevated temperatures [49]. Figure 3.4a shows a scanning transmission electron micrograph (STEM) of single crystalline c-(Ti $\left.\mathrm{Ti}_{0.6}, \mathrm{Al}_{0.4}\right) \mathrm{N}$ films on $\mathrm{MgO}$ (100) substrate. Starting from the STEM image, an FFT algorithm has been used to process the real-space image. Figure $3.4 \mathrm{~b}$ shows the FFT with well-defined spots, which corresponds to the contribution of different crystallographic planes. A mask is applied on specific 110 spots in the FFT image then inverse FFT algorithm is performed to reconstruct a high-resolution real space image (Figure 3.4c). The insets 1, 2 and 3 are three different regions showing the presence of defects such as lattice distortions and edge dislocations in the (110) planes. From this technique, the presence of mismatch-related defects as well as dislocations from Ti-rich or Al-rich regions could be observed. The small differences in the lattice parameters ( $\mathrm{a}_{\mathrm{o}}$ ) and coefficient of thermal expansions (a) of (Ti,Al)N film and $\mathrm{MgO}$ substrate would result to a generation of strain in the epitaxially grown films. This is because the lattice mismatch values 
between the film and the substrate results in misfit dislocations and the difference in $\alpha$ results in biaxial residual stress [6o, 61].

The dislocation structure and microstrain evolution during spinodal decomposition of epitaxially grown c-( $\left.\mathrm{Ti}_{1-x}, \mathrm{Al}_{\mathrm{x}}\right) \mathrm{N}$ are presented in Paper 3 [62] and Paper 5 [71]. It is essential to fabricate single crystal $\left(\mathrm{Ti}_{1-\mathrm{x}}, \mathrm{Al}_{\mathrm{x}}\right) \mathrm{N}_{\mathrm{y}}$ films with low level of impurities in order to observe the details of their defect structure. In the paper, geometric phase analysis (GPA) on high-resolution STEM images was employed for the atomic resolution strain analysis. The study shows that the chemical bonding state and elastic properties of the TiN- and AlN- rich domains have influenced the defect structure and strain generation during decomposition. 


\section{Coating Deposition}

The $\left(\mathrm{Ti}_{1-\mathrm{x}}, \mathrm{Al}_{\mathrm{x}}\right) \mathrm{N}_{\mathrm{y}}$ thin films used in this study are fabricated using cathodic arc deposition and DC magnetron sputtering, which are both plasma based physical vapor deposition (PVD) techniques. Cathodic arc deposition was used to deposit poly-crystalline wear resistive coatings on WC-Co substrates for metal cutting applications while the magnetron sputtering was used to deposit single-crystalline model system thin film materials on $\mathrm{MgO}$ substrates. The fundamental principle and mechanism of these two deposition techniques are described in this chapter.

\subsection{Cathodic arc evaporation}

Cathodic arc deposition is a technique widely used in coating industries because it has significantly higher deposition rate as compared to other PVD methods such as magnetron sputtering [63]. The deposition process starts by igniting an arc, which is typically done by a rapid contact of a mechanical trigger wire with the cathode [64]. This generates a cathode spot, which is a small highly energetic emitting area with high-localized temperature (5000 to $10000{ }^{\circ} \mathrm{C}$ ) [65]. The solid material in the cathode spot transforms to a highpower density cathodic arc, which comprises of multiple charged metal ions, neutral particles, clusters, and macroparticles. A cathodic arc is a high current, low voltage discharge that is usually operated in the continuous direct current (DC) mode with an arc current between 50 to 150 A [63]. In a reactive arc deposition, a reactive gas such as $\mathrm{N}_{2}$ is introduced in the chamber during the evaporation process. Dissociation, ionization and excitation occur in the interaction between the reactive gas and the ion flux [66]. These plasma particles condense on the substrate to form the compound film.

The investigated $\left(\mathrm{Ti}_{1-\mathrm{x}} \mathrm{Al}_{\mathrm{x}}\right) \mathrm{N}_{\mathrm{y}}$ films in Paper 1 and Paper 2 are grown using an industrial scale arc-evaporation deposition system [54, 67], which is schematically illustrated in Figure 4.1a. Three cathodes with different composition are placed in a vertical row (positions A-C) while substrates are placed at different heights (positions 1-5) opposite to the cathodes on a rotating cylinder. Through plasma mixing, thin films with different compositions were synthesized in one batch of deposition (Figure 4.1b). The nitrogen content of the $\left(\mathrm{Ti}_{1-\mathrm{x}}, \mathrm{Al}_{\mathrm{x}}\right) \mathrm{N}_{\mathrm{y}}$ films were controlled by varying the ratio 
of the gas flow ratio of the $\mathrm{N}_{2} /\left(\mathrm{Ar}+\mathrm{N}_{2}\right)$ gas mixture. The gases were introduced through pipes positioned vertically in the chamber.

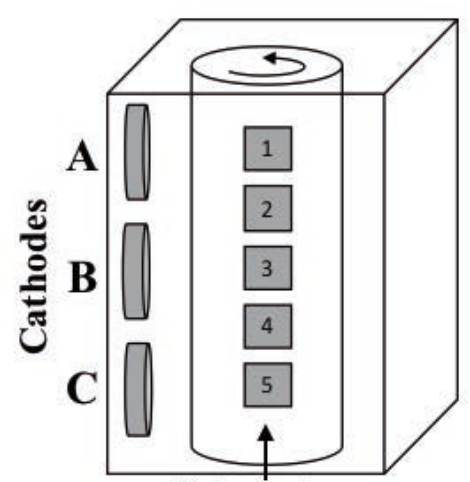

Substrates

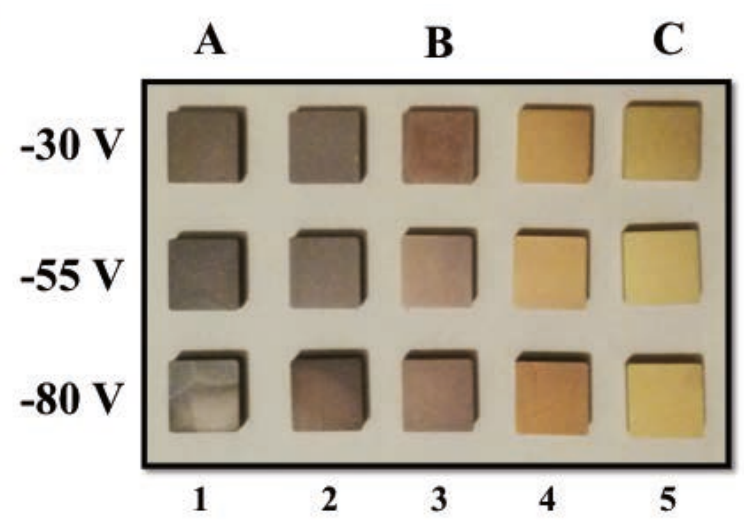

\section{A: $\mathbf{T i}_{0.33} \mathbf{A l}_{0.67}, \mathbf{B}: \mathbf{T i}_{0.45} \mathbf{A l}_{0.55}, \mathrm{C}: \mathbf{T i}$}

Figure 4.1. (left) Schematic diagram of the cathodic arc deposition set-up and (right) the films with varying nitrogen flow rate and applied bias voltage that were produced in this set-up.

The microstructure and phase evolution of $\left(\mathrm{Ti}_{1-\mathrm{x}} \mathrm{Al}_{\mathrm{x}}\right) \mathrm{N}_{\mathrm{y}}$ films are influenced by the nitrogen vacancies and the applied bias voltage on the substrates. Schramm et al. $[14,68]$ have pioneered the experimental investigation of the effect of nitrogen vacancies on polycrystalline cathodic arc films. In Paper 1, the effects of the applied bias voltage on the microstructural evolution and phase transition of nitrogen deficient films are investigated [54]. Bias voltage is a critical factor in this study because it affects the ion energy impinging on surface and influence the nucleation and growth kinetics during the film growth.

One drawback of the cathodic arc deposition technique is the presence of macroparticles. Our study shows that both the amount and size of macroparticles are dependent on the applied negative substrate bias voltage on the substrate (Paper 1) and the $\mathrm{N}$ content in the films (Paper 2). The amount of macroparticles increases as the applied substrate bias and the film $\mathrm{N}$ content decrease. Figure 4.2 shows the high-angle annular dark field (HAADF) STEM micrograph and STEM-EDX (energy dispersive x-ray spectroscopy) of $\left(\mathrm{Ti}_{0.52}, \mathrm{Al}_{0.48}\right) \mathrm{N}_{0.75}$ (i.e. coating with the lowest nitrogen content among the studied samples), which reveals an inhomogeneous concentration of elements inside the macroparticle. A relatively high concentration of Ti elements is observed in the bottom region of the macroparticle, which are excess neutral atoms commonly observed in (Ti,Al)N films deposited using cathodic arc 
technique $[6,69,70]$. The detrimental effect of macroparticles on the wear behavior of $\left(\mathrm{Ti}_{1-\mathrm{x}}, \mathrm{Al}_{\mathrm{x}}\right) \mathrm{N}_{\mathrm{y}}$ films is discussed in Chapter 6 .

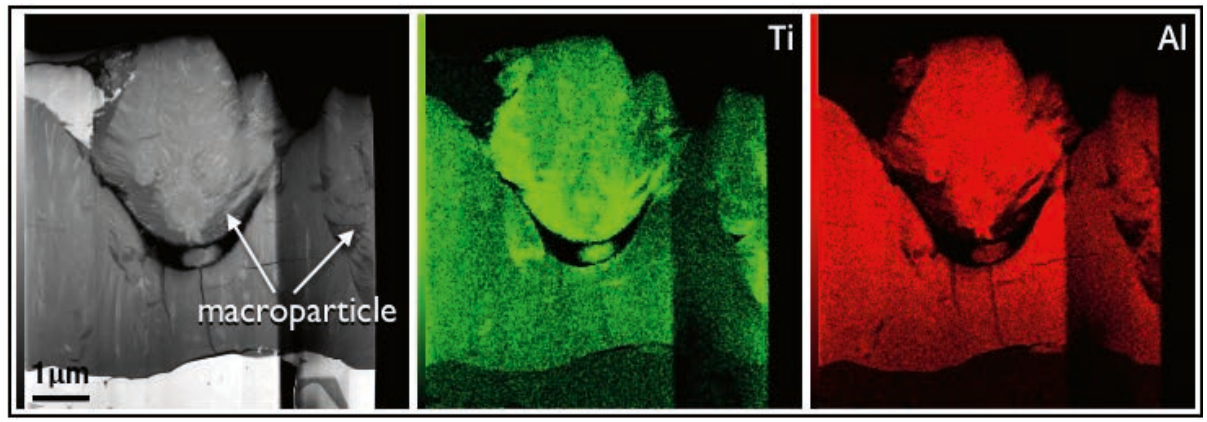

Figure 4.2. HAADF-STEM and STEM-EDX of $\left(\mathrm{Ti}_{0.52} \mathrm{Al}_{0.48}\right) \mathrm{N}_{0.75}$ coatings.

\subsection{DC magnetron sputtering}

DC magnetron sputtering is a deposition technique utilized in this thesis for growth of single crystalline $\left(\mathrm{Ti}_{1-\mathrm{x}}, \mathrm{Al}_{\mathrm{x}}\right) \mathrm{N}_{\mathrm{y}}$ films (examined in Papers 3 to 5) [45, 67, 71]. These films exhibit homogeneous microstructures free of macroparticles. In sputtering process, the surface or near-surface atoms of cathode (target) are ejected by the bombardment of incident particles with sufficient energy to break bonds and dislodge atoms [72]. In contrast to cathodic arc, sputter deposition is a high-voltage, low current discharge process. Figure 4.3 shows the schematic diagram of a typical sputtering set-up. The process starts by applying voltage across electrodes to generate an electric field that accelerates free electrons towards the anode. These electrons gain energy and collide with the chemically inert sputtering gas such as Ar, causing the gas to breakdown into a plasma discharge. The ions are accelerated to the negatively biased cathode and cause collision cascade and sputtering of the target surface atoms. This ion bombardment also causes the ejection of secondary electrons from the target, which results to further ionization of gas atoms that can sustain the discharge.

In magnetron sputtering, a magnetic field is placed parallel to the target surface to confine the secondary electrons close to the target surface. The magnetic field captures and prolongs the electron spiral motion along the field lines. This technique increases the sputtering rate because highly concentrated electron gas will have more collisions, resulting to an increase in ion bombardment of the target surface. Consequently, the deposition rate of the magnetron sputtering is enhanced. In this thesis, a reactive nitrogen gas $\left(\mathrm{N}_{2}\right)$ is 
also introduced in the chamber. The sputtered particles undergo a chemical reaction with the reactive gas on the film surface to form the compound. The nitrogen content of the $\left(\mathrm{Ti}_{1-\mathrm{x}}, \mathrm{Al}_{\mathrm{x}}\right) \mathrm{N}_{\mathrm{y}}$ films is controlled by varying the $\mathrm{N}_{2}$ to $\mathrm{Ar}$ flow ratio.

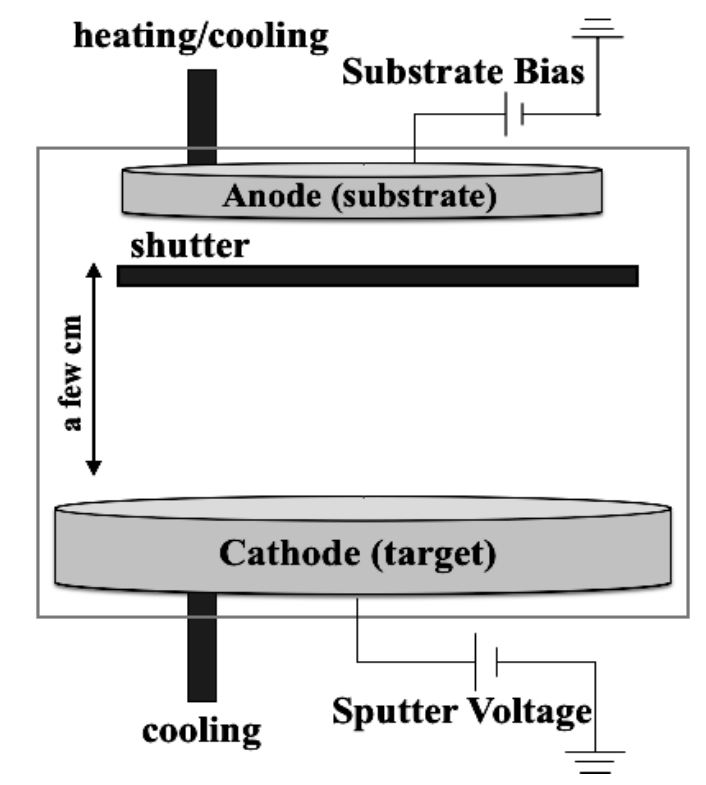

Figure 4.3. Schematic diagram of a sputtering set-up.

\subsubsection{Growth Conditions}

During sputtering deposition, the energetic particles (adatoms, ions, etc.) impinging on the growth surface, their energy distributions and their effect on film formation (nucleation and growth mechanism) are mainly controlled by: sputter voltage, gas flow rate and pressure, substrate bias voltage, and substrate temperature $[6,72,73]$.

In the present study, the discharge current (i.e. directly proportional to the sputter yield) was held constant and no substrate bias was applied. Further, the substrate temperature, gas pressure, and gas flow rate were optimized to yield single crystalline (Ti,Al)N films [11, 12, 49]. The substrate temperature of the films must be high enough to provide sufficient adatom mobilities promoting epitaxial growth [13]. In a previous study on epitaxial TiN growth, it was reported that a minimum substrate temperature of $200{ }^{\circ} \mathrm{C}$ was required to attain epitaxial growth on $\mathrm{MgO}$ substrate [74]. To obtain TiN films with a crystal coherence length comparable to the film thickness required a growth 
temperature of at least to $600{ }^{\circ} \mathrm{C}$ [74]. The fabricated single crystalline (Ti,Al)N films in this study are deposited at a substrate temperature of $700{ }^{\circ} \mathrm{C}$ $[45,62,71]$.

The preferred orientation of the deposited (Ti,Al)N on this study is controlled by the balance between surface energy and strain energy, which are influenced by working pressure and nitrogen gas flow rate $[11,12]$. At a high $\mathrm{N}_{2}$ flow, the surface mobility of the adatoms decreases and thus favors the growth of (200) lattice crystal planes having a higher ledge energy and a shorter diffusion distance relative to planes with lower energy sites $[14,15]$. Further increase of the $\mathrm{N}_{2}$ is not necessary because it would reduce the deposition rate and would also lead to nitrogen-poisoned growth mode [16]. In fact, the overall pressure should not be too high, because the electrons need to gain enough energy between collisions, nor too low, since gas collisions are essential in sustaining the plasma. Growth of single crystalline (Ti,Al)N films on $\mathrm{MgO}$ substrates as a function of N-content are studied in Paper 5 [71].

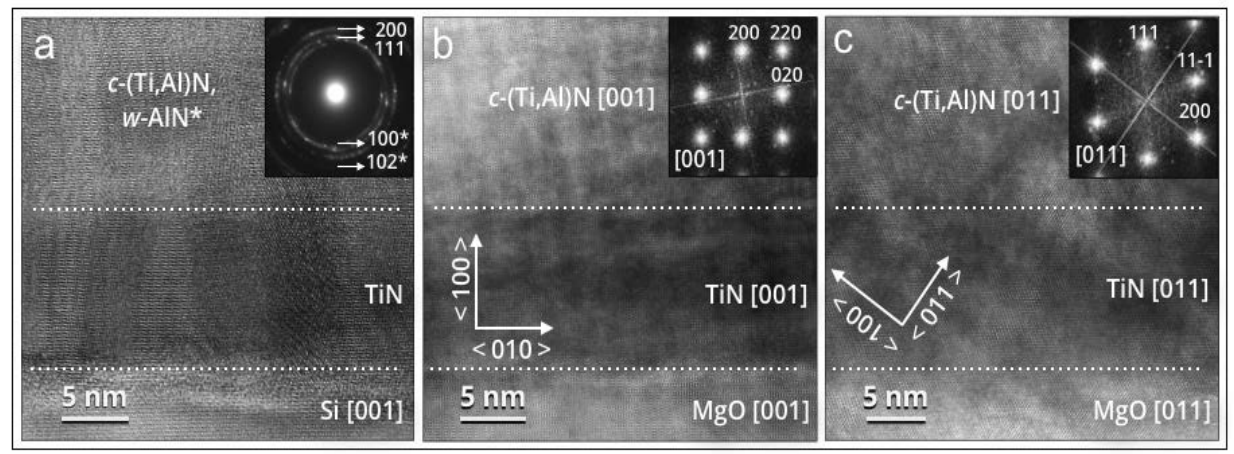

Figure 4.4. (a) HRTEM with SAED inset of (Ti,Al)N on Si, (b) HRTEM with FFT inset of (Ti,Al)N on $\mathrm{MgO}(\mathrm{OO} 1)$, and (c) HRTEM with FFT inset of (Ti,Al)N on $\mathrm{MgO}(111)$. The diameter of the sample area used for SAED is $100 \mathrm{~nm}$.

\subsubsection{Effect of Substrate}

It is necessary that the lattice parameters of the substrate and the film have a good match to achieve heteroepitaxial growth. The theory of Frank and van der Merwe predicts that a lattice parameter mismatch of less than $9 \%$ is required to obtain an epitaxial layer [22]. A too large lattice mismatch would result in the growth of polycrystalline film due to the existence of a high dislocation density at the substrate-film interface [23]. 
Another important aspect for the conditions of epitaxial growth is the effect of thermal strain, which may exceed the lattice mismatch strain for a given film/substrate system. A large difference in the thermal expansion coefficients between the film and the substrate in combination with a high growth temperature can cause a large thermal strain when cooling down to room temperature [24]. Thus, it is also necessary that the thermal coefficients of both film and substrate to be in the same order of magnitude to grow high quality epitaxial films. Figure 4.4 shows high resolution transmission electron microscopy (HRTEM) images of (Ti,Al)N films deposited on $\mathrm{Si}, \mathrm{MgO}$ (oo1) and $\mathrm{MgO}$ (111) substrates. Epitaxial films are only achieved on MgO substrates. This demonstrate that $\mathrm{MgO}$ is a good choice of substrate because the lattice mismatch between the nitride films is less than $9 \%$ and their thermal coefficients are of the same order. The lattice mismatch of $\mathrm{MgO}$ and c-TiN buffer layer with respect to the film is $1.43 \%$ and $2.12 \%$, respectively (details of the computation are shown in the manuscript). The thermal coefficients of $\mathrm{MgO}$, TiN, and $(\mathrm{Ti}, \mathrm{Al}) \mathrm{N}$ are $\alpha_{\mathrm{MgO}} \approx 4.0 \times 10^{-6} /{ }^{\circ} \mathrm{C}, \alpha_{\mathrm{TiN}} \approx 10.3 \times 10^{-6} /{ }^{\circ} \mathrm{C}$, and $\alpha_{\mathrm{MgO}} \approx 7.5 \times 10^{-6} /{ }^{\circ} \mathrm{C}$, respectively $[25,26]$.

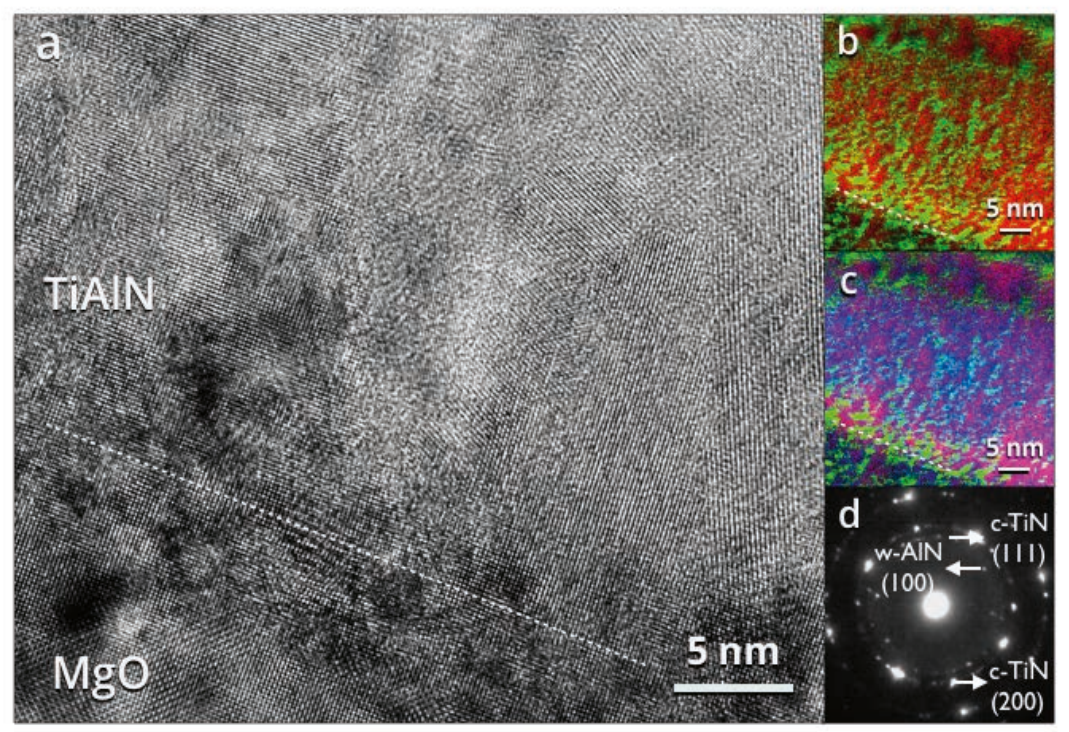

Figure 4.5. (a) HR-TEM, (b) EFTEM: Ti (red), Al (green), (c) EFTEM: Ti (red), Al (green), N(blue), and d) SAED of (Ti,Al)N/MgO annealed at $900{ }^{\circ} \mathrm{C}$.

Figure 4.5a shows the HRTEM micrographs of (Ti,Al)N film grown directly on $\mathrm{MgO}$ and was subsequently annealed at $900{ }^{\circ} \mathrm{C}$. Different orientations of domains and grain boundaries are observed in the annealed sample. Figures $4.5 \mathrm{~b}$ and $4.5 \mathrm{c}$ show energy filtered TEM (EFTEM) images of the film revealing 
the clear segregation on the metal sublattice while N-sublattice segregation cannot be detected. $\mathrm{Al}$ has diffused on to the $\mathrm{MgO}$ substrate because $\mathrm{Al}$ and $\mathrm{Mg}$ chemically reacts to form spinel [75]. At this temperature, (Ti,Al)N has already decomposed and an early sign of w-AlN transformation can be seen, as confirmed from the selected area electron diffraction (SAED) pattern (Figure 4.5d). The studied (Ti,Al)N films in Papers 3, 4, and 5 were all grown with TiN buffer layers $[45,62,71]$. The thin TiN buffer layer prevents high temperatures chemical reaction between $\mathrm{Al}$ and $\mathrm{Mg}$. 


\section{Metal Cutting}

By tuning the nitrogen content and point defect concentration in c-(Ti,Al)N films, we have demonstrated a significant enhancement of its thermal stability, i.e. which results in a delayed onset of the detrimental w-AlN phase to $1100{ }^{\circ} \mathrm{C}$ (Paper 1) [54]. The improved thermal stability in nitrogen deficient $\left(\mathrm{Ti}_{1-\mathrm{x}} \mathrm{Al}_{\mathrm{x}}\right) \mathrm{N}_{\mathrm{y}}$ $(\mathrm{y}<1)$ coatings has been explained by the presence of $\mathrm{N}$ vacancies and a reduced driving force for decomposition [13]. The thermal stability and mechanical properties of these coatings were determined by examining their microstructure and hardness after annealing in a vacuum furnace to high temperatures where decomposition has already taken place. During machining, the coatings are subjected to harsh conditions such as high temperature, pressure and corrosive chemistry, which for example results in high stress levels and chemical interactions with the workpiece material, which lead to wear and plastic deformation [76-78]. In this chapter, the microstructure and chemical reaction of nitrogen deficient coatings that are exposed to a cutting process is discussed to gain insight on the wear mechanism of cutting tools.

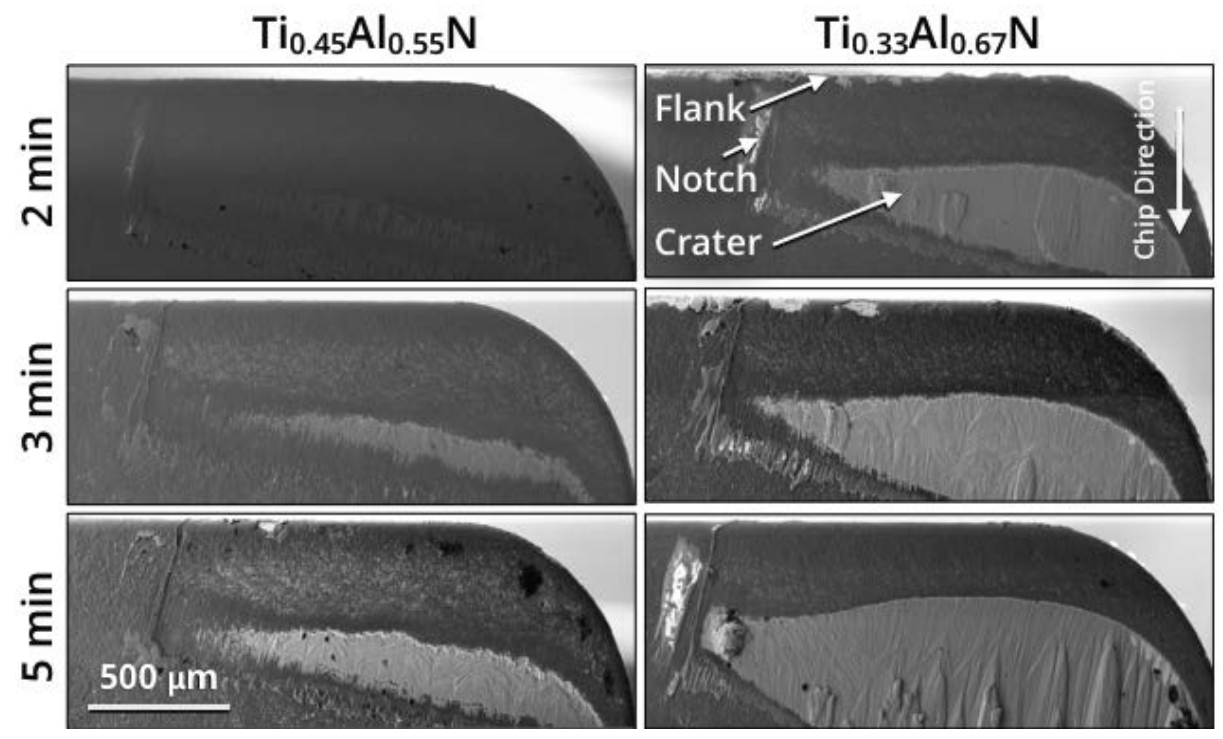

Figure 5.1 SEM micrographs of $\left(\mathrm{Ti}_{1-\mathrm{x}}, \mathrm{Al}_{\mathrm{x}}\right) \mathrm{N}_{\mathrm{y}}(\mathrm{y} \approx 1)$ films with different $\mathrm{Al}$ content after 2min, $3 \mathrm{~min}$, and $5 \mathrm{~min}$ exposure to metal cutting. 


\subsection{Wear Mechanism}

The wear mechanism of a cutting tool during machining depends on the workpiece material, properties of the cutting tool, cutting conditions, and cooling or lubrication system [79]. The most common types of tool wear are crater wear, flank wear, and notch wear (depth-of-cut) (Figure 5.1). During cutting, the sliding of the chip that has been removed from the workpiece material generates high temperatures and shear stresses in the contact area of the rake face [8o]. This leads to the generation of crater wear, which is a major cause of accelerated tool failure during the machining of metal alloy components. Flank wear occurs on the relief face and it is mainly due to the abrasion of the cutting edge. A notch wear occurs at the point of contact between the tool and the free edge of the chip and it is mainly due to abrasion and oxidation if a coolant is used.

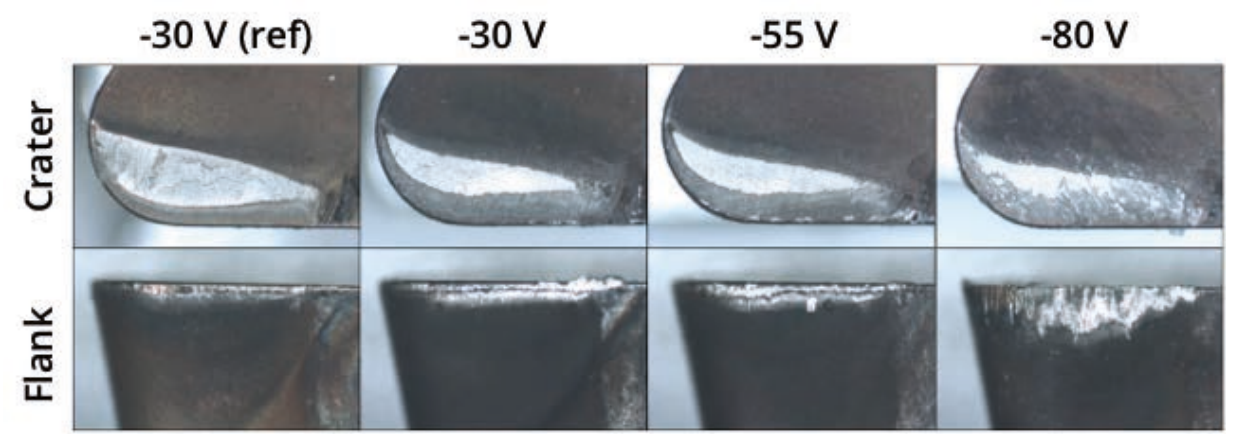

Figure 5.2 Crater and flank wear of a stoichiometric ( $\left.\mathrm{Ti}_{0.54}, \mathrm{Al}_{0.46}\right) \mathrm{N}$ film biased at $-30 \mathrm{~V}$ and nitrogen deficient ( $\left.\mathrm{Ti}_{0.54} \mathrm{Al}_{0.46}\right) \mathrm{N}_{0.87}$ films biased at $-30 \mathrm{~V},-55 \mathrm{~V}$, and $-8 \mathrm{o} \mathrm{V}$.

The progression of wear on stoichiometric $\left(\mathrm{Ti}_{1-\mathrm{x}}, \mathrm{Al}_{\mathrm{x}}\right) \mathrm{N}$ coatings with $\mathrm{Al}$ content of $\mathrm{x}=0.54$ and $\mathrm{x}=0.67$ is shown in Figure 5.1. The $\left(\mathrm{Ti}_{0.46}, \mathrm{Al}_{0.54}\right) \mathrm{N}$ coating has higher wear resistance than $\left(\mathrm{Ti}_{0.33}, \mathrm{Al}_{0.67}\right) \mathrm{N}$ because less w-AlN is formed [30]. In paper 1, the effect of bias voltage on the ex-situ high temperature hardness of nitrogen deficient $\left(\mathrm{Ti}_{0.46}, \mathrm{Al}_{0.54}\right) \mathrm{N}_{0.87}$ was investigated [54]. The cutting performance of these films was tested in steel and the results are shown in Figure 5.2. The low biased nitrogen deficient films (-30 V and $-55 \mathrm{~V})$ have better crater and flank wear resistance as compared to the high biased sample $(-80 \mathrm{~V})$ and the stoichiometric film biased at $-30 \mathrm{~V}$. The film biased at $-80 \mathrm{~V}$ has the least wear resistance among the samples. The $\left(\mathrm{Ti}_{0.46}, \mathrm{Al}_{0.54}\right) \mathrm{N}_{0.87}$ film, grown with a biased of $-55 \mathrm{~V}$ exhibits a higher hardness and a lower amount of macroparticles as compared to the film biased at $-30 \mathrm{~V}$ (shown in Paper 1). Figure 5.3 shows that after a prolonged exposure of the $\mathrm{c}-\left(\mathrm{Ti}_{0.48}, \mathrm{Al}_{0.52}\right) \mathrm{N}_{0.87}$ coating to metal cutting, crack has propagated from the macroparticles. One of 
the major causes of failure during wear cycling is the presence of these local macroscopic droplets [6]. In paper 2, the applied negative bias voltage was held constant at $-55 \mathrm{~V}$ and the effect of nitrogen content on the wear behavior of the $\mathrm{c}-\left(\mathrm{Ti}_{0.46}, \mathrm{Al}_{0.54}\right) \mathrm{N}_{\mathrm{y}}(\mathrm{y}=0.92, \mathrm{y}=0.87, \mathrm{y}=0.75)$ coatings are investigated [67].

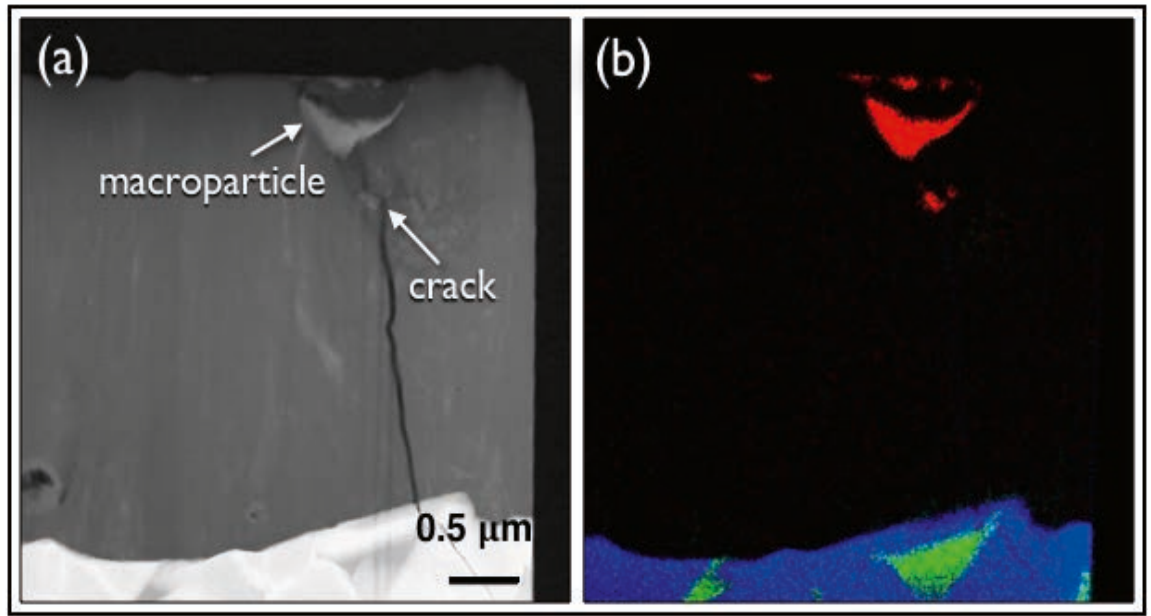

Figure 5.3. HAADF-STEM and STEM-EDX of c-(Tiio.52, $\left.\mathrm{Al}_{0.48}\right) \mathrm{N}_{\mathrm{y}}$ coatings with $\mathrm{y}=0.92$ after metal cutting. The colored areas are Fe (red) from the chip and Co (green) and $\mathrm{W}$ (blue) in the substrate.

\subsection{Effect of microstructure and chemical interaction}

It has been shown that c-(Ti,Al)N coatings are in a coarsened and decomposed state after 10 min of continuous turning of a carbon steel [81]. However, the initial state of their microstructure during turning is still unknown. Knowing such information is essential in determining the mechanism driving the wear behavior of such coatings. Figure 5.4 shows the crater wear of c-( $\left.\mathrm{Ti}_{1-\mathrm{x}}, \mathrm{Al}_{\mathrm{x}}\right) \mathrm{N}_{\mathrm{y}}(\mathrm{y}$ $=0.92, \mathrm{y}=0.87$, and $\mathrm{y}=0.75$ ) coatings after $1 \mathrm{~min}$ of cutting. In this initial stage of cutting, the crater wear of samples with different $x$ and $y$ compositions are similar. However, the microstructure and chemical interactions between these samples are different. FIB samples were taken along the chip direction near crater wear at around half of the cutting length at the chip-rake interface, where maximum temperature and maximum shear stress are expected. 


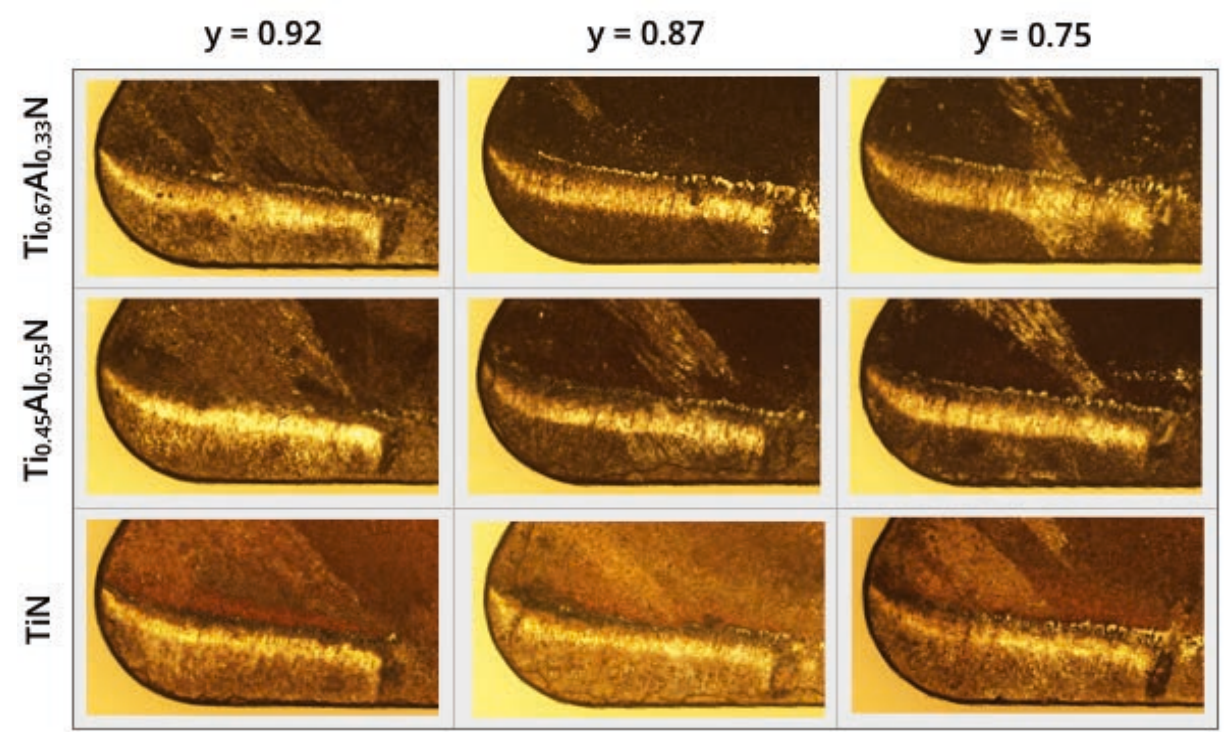

Figure 5.4 Optical micrographs of nitrogen deficient $\mathrm{c}-\left(\mathrm{Ti}_{1-\mathrm{x}}, \mathrm{Al}_{\mathrm{x}}\right) \mathrm{N}_{\mathrm{y}}$ film after $1 \mathrm{~min}$ of metal cutting.

High resolution cross-sectional dark field STEM images and the corresponding EDX maps of $\mathrm{c}-\left(\mathrm{Ti}_{0.52}, \mathrm{Al}_{0.48}\right) \mathrm{N}_{\mathrm{y}}(\mathrm{y}=0.92, \mathrm{y}=0.87$, and $\mathrm{y}=0.75)$ coatings with different $\mathrm{N}$ stoichiometry after they are exposed to $1 \mathrm{~min}$ of metal cutting are shown in Figure 5.5. The $y=0.92$ sample has a phase segregation of coherent c-TiN rich and c-AlN rich domains due to spinodal decomposition while the $y$ $=0.87$ sample has retained its as-deposited c-(Ti,Al)N structure. The microstructure is less dense in a decomposed state, thus it is more favorable for Fe from the workpiece to diffuse through the coating. The c-(Ti $\left.i_{0.52}, \mathrm{Al}_{0.48}\right) \mathrm{N}_{\mathrm{y}}$ $(y=0.75)$ contains $\mathrm{Ti}_{2}$ AlN MAX phase in some parts of the coating because high amount of nitrogen vacancies has as a driving force for the stabilization of hexagonal MAX phases [13]. Flank wear is mainly affected by the hardness of the coatings $[82,83]$. The c- $\left(\mathrm{Ti}_{0.52} \mathrm{Al}_{0.48}\right) \mathrm{N}_{0.92}$ coating has the best flank wear resistance it exhibits an age hardening effect due to spinodal decomposition. The c- $\left(\mathrm{Ti}_{0.52}, \mathrm{Al}_{0.48}\right) \mathrm{N}_{0.75}$ coating has the least flank wear resistance due the occurrence of $\mathrm{Ti}_{2} \mathrm{AlN}$ MAX phase within the coating, which has lower hardness than c-(Ti,Al)N [84]. 

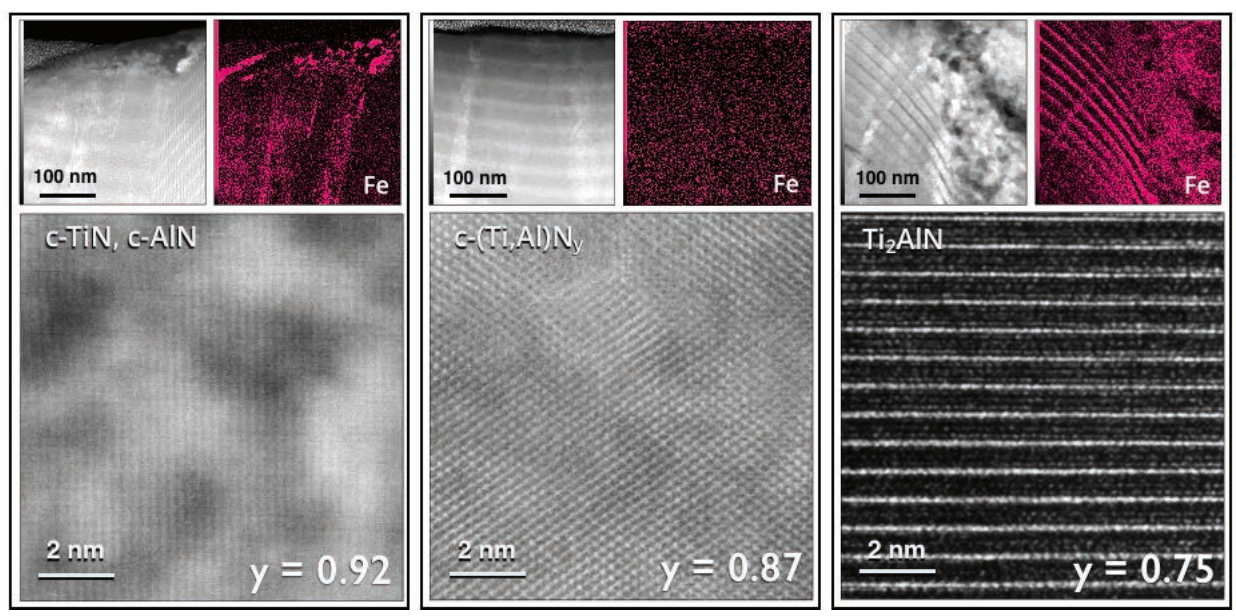

Figure 5.5 HAADF-STEM images and STEM-EDX of c-( $\left.\mathrm{Ti}_{0.52}, \mathrm{Al}_{0.48}\right) \mathrm{N}_{\mathrm{y}}$ coatings with $\mathrm{y}=$ $0.92, \mathrm{y}=0.87$, and $\mathrm{y}=0.75$ after $1 \mathrm{~min}$ of metal cutting.

The high-speed cutting of the steel workpiece has facilitated the abrasive wear, chemical interaction with the chip, and plastic deformation of the $c-\left(\mathrm{Ti}_{1-\mathrm{x}} \mathrm{Al}_{\mathrm{x}}\right) \mathrm{N}_{\mathrm{y}}$ $(y=0.92, y=0.87$, and $y=0.75)$ coatings of the tool inserts. The overview of the cross sectional STEM images and the corresponding EDX maps of c$\left(\mathrm{Ti}_{0.52}, \mathrm{Al}_{0.48}\right) \mathrm{N}_{\mathrm{y}}$ coatings with different $\mathrm{N}$ content after exposure to 1 min of metal cutting are shown in Figure 5.6. Large macroparticles are observed in the $\mathrm{y}=0.75$ sample. Chemical maps of the cross sections show that the elements from the workpiece material, for example $\mathrm{Fe}$ and $\mathrm{Cr}$, are mostly concentrated to the top surface and at macroparticle boundaries. There is no cobalt found in the $\mathrm{y}=0.92$ and $\mathrm{y}=0.87$ samples while cobalt has diffused from the WC-Co substrate to the large macroparticle in the $y=0.75$ sample. In paper 2, the compositional homogeneity and the chemical reaction between elements from the workpiece and the coatings are further discussed. Crater wear is mainly caused by chemical wear due to diffusion [76]. The c$\left(\mathrm{Ti}_{0.52}, \mathrm{Al}_{0.48}\right) \mathrm{N}_{0.87}$ coating has better crater wear resistance than c$\left(\mathrm{Ti}_{0.52}, \mathrm{Al}_{0.48}\right) \mathrm{N}_{0.92}$ because there it contains lesser chip elements that diffused through the coating. The c- $\left(\mathrm{Ti}_{0.52}, \mathrm{Al}_{0.48}\right) \mathrm{N}_{0.75}$ coating has the least crater wear resistance among the samples due to its high amount of macroparticles, which facilitate the diffusion of chip elements (e.g. Fe and Co) and can weaken its structure through recrystallization [85]. 

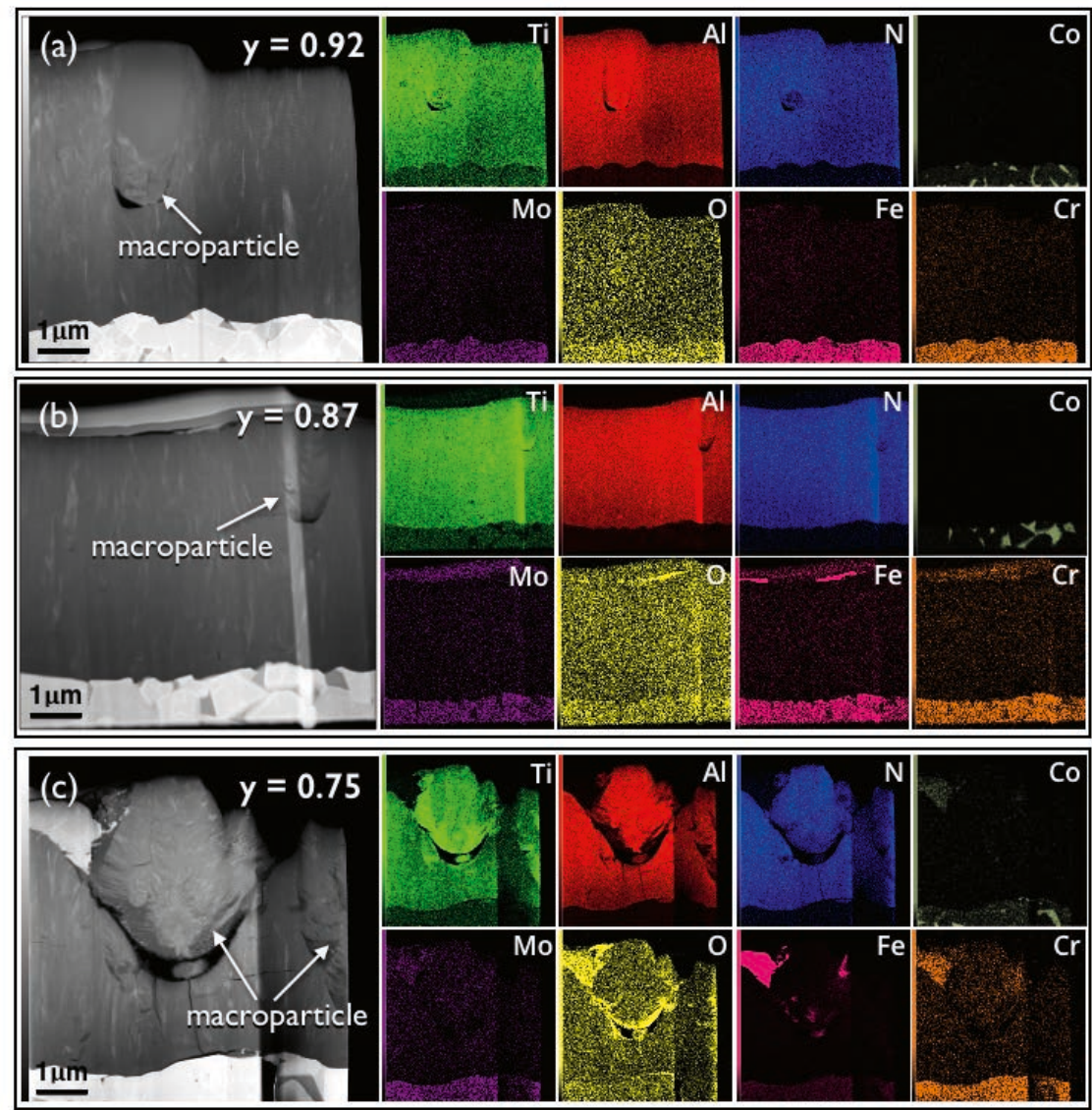

Figure 5.6. HAADF-STEM and STEM-EDX of $\left(\mathrm{Ti}_{0.52}, \mathrm{Al}_{0.48}\right) \mathrm{N}_{\mathrm{y}}$ coatings with (a) $\mathrm{y}=$ 0.92 , (b) $y=0.87$, and (c) $y=0.75$ after 1 min of metal cutting. The regions in the right side of the FIB samples are thinner in comparison to the other side. The transition in thickness is indicated by the sharp brightness difference in the STEM and STEM-EDX images. 


\section{Characterization techniques}

\subsection{XRD}

X-ray diffraction (XRD) techniques are used to obtain crystallographic information and phase structure of the poly- and single- crystalline (Ti,Al)N films. This technique is based on Bragg's law, given by:

$$
2 d \sin \theta=n \lambda
$$

where $d$ is the interplanar distance, $\theta$ is the scattering angle of the incident or diffracted ray, $n$ is an integer, and $\lambda$ is the wavelength of the of the incident ray. In this technique, incident $\mathrm{x}$-rays are first directed towards the crystalline sample. Diffraction is produced at certain angles (Bragg's angle) where x-rays are coherently scattered. The X-ray diffraction $\theta-2 \theta$ scans, azimuthal scans, rocking curves, residual stress, and reciprocal space maps of the films were acquired using PANalytical Empyrean and PANalytical X'Pert PRO MRD diffractometers with $\mathrm{Cu} \mathrm{K}_{a}$ radiation.

\subsubsection{Residual stress}

The strain measurements of the nitrogen deficient $\mathrm{c}-\left(\mathrm{Ti}_{0.54}, \mathrm{Al}_{0.46}\right) \mathrm{N}_{\mathrm{y}}$ films deposited using cathodic arc technique were obtained using the $\sin ^{2}(\psi)$ method [86] on the 422 diffraction line. In this technique, the (hkl) plane spacings are measured by using $\theta-2 \theta$ scans in directions inclined by the angle $\psi$. Then, the lattice spacing $\left(\epsilon_{\psi}\right)$ vs. $\sin ^{2} \psi$ are plotted to get the slope of the curve. The in-plane stress $\left(\sigma_{\|}\right)$can be obtained because it is related to the measured slope, elastic modulus $(E)$, and Poisson ratio $(v)$ of the material. The fundamental equation used in the XRD residual stress analysis is shown in Eq. (1).

$$
\epsilon_{\psi}=\frac{d_{\psi-} d_{0}}{d_{0}}=\frac{1+v}{E} \sigma_{\|} \sin ^{2} \psi-\frac{2 v}{E} \sigma_{\|}
$$

where $E$ and $v$ of the films are taken from $a b$ initio calculations [34]. 


\subsubsection{Reciprocal space maps}

Symmetric and asymmetric x-ray diffraction reciprocal space maps (RSM) of epitaxial $\left(\mathrm{Ti}_{1-\mathrm{x}}, \mathrm{Al}_{\mathrm{x}}\right) \mathrm{N}_{\mathrm{y}}$ films were acquired using a PANalytical Empyrean diffractometer with $\mathrm{Cu} \mathrm{K}_{a}$ radiation. In this technique, the reciprocal lattice vectors $\boldsymbol{Q}_{\mathbf{c}}$ and $\boldsymbol{Q}_{\mathbf{a}}$ are obtained using Eqs. (2) and (3), which are related to the out-of-plane $\left(d_{c}\right)$ and in-plane $\left(d_{\mathrm{a}}\right)$ lattice parameters of the films, respectively.

$$
\begin{aligned}
& \boldsymbol{Q}_{\mathrm{c}}=\frac{4 \pi}{\lambda} \sin \theta \cos (\theta-\omega)=\frac{2 \pi}{d_{\mathrm{c}}} \\
& \boldsymbol{Q}_{\mathrm{a}}=\frac{4 \pi}{\lambda} \sin \theta \sin (\theta-\omega)=\frac{2 \pi}{d_{\mathrm{a}}}
\end{aligned}
$$

where $\omega$ and $\theta$ are the instrumental coordinates and $\lambda$ is the $\mathrm{x}$-ray wavelength.

\subsubsection{Pole Figures}

A pole figure shows a 2D stereographic projection of the orientation for a selected set of crystal plane. The XRD pole figures of the $\left(\mathrm{Ti}_{0.23}, \mathrm{Al}_{0.77}\right) \mathrm{N}$ films grown on $\mathrm{MgO}(111)$ substrates were obtained using a PANalytical Empyrean diffractometer with a 4-axis goniometer, a channel-cut 2-bounce $\mathrm{Ge}(220)$ monochromator (primary optics), and a parallel plate collimator (secondary optics).

\subsection{SEM}

The surface morphologies of the $\left(\mathrm{Ti}_{1-\mathrm{x}}, \mathrm{Al}_{\mathrm{x}}\right) \mathrm{N}_{\mathrm{y}}$ coatings were obtained using FEI Helios nanolab 600 and Leo 1550 Gemini scanning electron microscopes (SEM). The wear behavior of the ( $\left.\mathrm{Ti}_{0.48}, \mathrm{Al}_{0.52}\right) \mathrm{N}_{\mathrm{y}}$ coatings was determined by measuring the area of the exposed substrate (crater wear) and the average flank wear land width from the SEM images. The Leo 1550 Gemini SEM equipped with energy dispersive X-ray spectroscopy (EDS) (Oxford X-Max) was used to determine the atomic composition of the targets and to obtain the elemental maps of the $\left(\mathrm{Ti}_{1-\mathrm{x}}, \mathrm{Al}_{\mathrm{x}}\right) \mathrm{N}_{\mathrm{y}}$ inserts after metal cutting. 


\subsection{FIB}

Focused ion beam (FIB) - SEM dual beam systems (Helios Nanolab 6ooi and Zeis Neon 40) were used to obtain cross-sectional transmission electron microscope (TEM) lamella. An in situ lift-out technique [87] was used to obtain samples with approximately $50 \mathrm{~nm}$ uniform thickness. Figure 6.1 shows the FIB images of the nitrogen deficient $\left(\mathrm{Ti}_{0.48}, \mathrm{Al}_{0.52}\right) \mathrm{N}_{\mathrm{y}}(\mathrm{y}=0.92,0.87$, and 0.75) coatings which are taken from the center of the crater area of the insert after metal cutting. Plan-view TEM samples of $\left(\mathrm{Ti}_{0.23}, \mathrm{Al}_{0.77}\right) \mathrm{N}$ were prepared by FIB-SEM dual beam system (Zeis Neon 40).

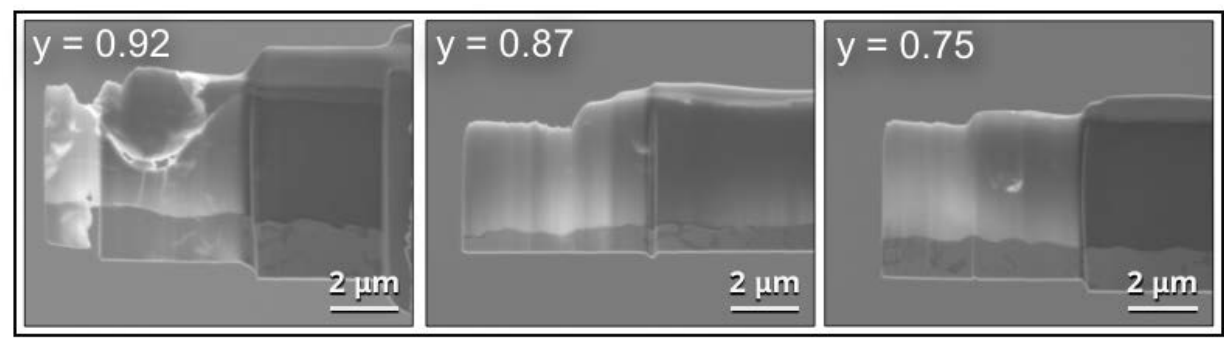

Figure 6.1 FIB images of the $\mathrm{c}-\left(\mathrm{Ti}_{0.52}, \mathrm{Al}_{0.48}\right) \mathrm{N}_{\mathrm{y}}$ coatings after 1 min of metal cutting.

\subsection{TEM}

Microstructural characterizations from TEM, energy-filtered TEM (EFTEM), dark field TEM, scanning TEM (STEM), and selected area electron diffraction (SAED) images of the c- $\left(\mathrm{Ti}_{1-\mathrm{x}}, \mathrm{Al}_{\mathrm{x}}\right) \mathrm{N}_{\mathrm{y}}$ films were obtained using JEOL ARM 200 Cold FEG and Fei Tecnai G2 TF 20 UT analytical TEM equipment. The TEMs are equipped with EDS for the chemical analyses of the samples. They were operated at an acceleration voltage of $200 \mathrm{kV}$. The samples were prepared using either FIB or the conventional technique (i.e. mechanical grinding and polishing, followed by sputter etching until the sample has $<100 \mathrm{~nm}$ thickness). The TEM samples used for the geometric phase analysis (GPA) analysis were prepared by FIB to ensure a uniform thickness.

\subsection{GPA Analysis}

The strain maps of the single crystalline c-(Ti,Al)N/c-(TiN) films on $\mathrm{MgO}$ substrates were obtained using a geometric phase analysis (GPA) script [88] added in the Gatan's Digital Micrograph. GPA is an image analysis method, 
which calculates the strain tensors of a high-resolution transmission electron microscope (TEM) image by measuring the positions of atomic columns relative to a reference region [89]. Figure 6.2 shows an example of a strain map from an HRTEM image.
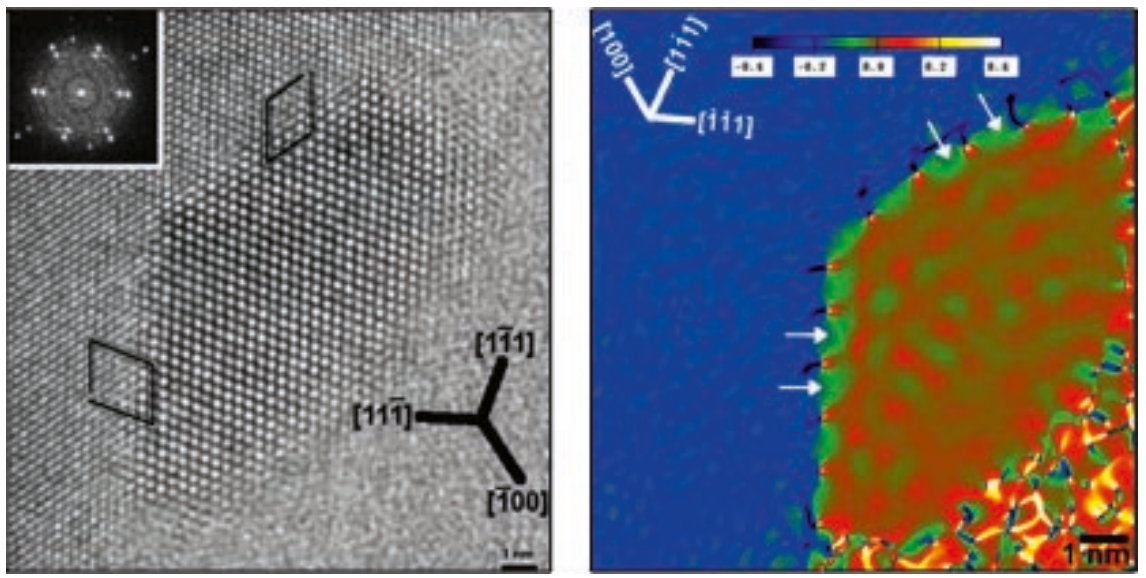

Figure 6.2. Strain mapping along $\mathrm{Al}-\mathrm{Pb}$ interfaces.

The equations below show the important phase relations involved in GPA. The intensity of a particular set of fringes in a high resolution TEM image, which is selected by applying a filter on Fourier component $\mathrm{g}$ is represented as:

$$
\boldsymbol{I}_{\boldsymbol{g}}(\boldsymbol{r})=A_{g}(\boldsymbol{r}) \exp \left[i \boldsymbol{P}_{\boldsymbol{g}}(\boldsymbol{r})\right]
$$

where $A_{g}(\boldsymbol{r})$ is the contrast level while $\boldsymbol{P}_{\boldsymbol{g}}(\boldsymbol{r})$ is the relative phase shift induced by a small displacement of the fringes $\boldsymbol{u}(\boldsymbol{r})$ with respect to a reference lattice, described as:

$$
\boldsymbol{P}_{\boldsymbol{g}}(\boldsymbol{r})=-2 \pi \boldsymbol{g} \cdot \boldsymbol{u}(\boldsymbol{r})
$$

The 2D displacement field is obtained by two non-collinear $\boldsymbol{g}$ :

$$
\boldsymbol{u}(\boldsymbol{r})=-\frac{1}{2 \pi}\left[\boldsymbol{P}_{\boldsymbol{g} 1}(\boldsymbol{r}) \boldsymbol{a}_{1}+\boldsymbol{P}_{\boldsymbol{g} 2}(\boldsymbol{r}) \boldsymbol{a}_{2}\right]
$$

where $\boldsymbol{a}_{1}$ and $\boldsymbol{a}_{2}$ are the real space lattice vector of $\boldsymbol{g}_{1}$ and $\boldsymbol{g}_{1}$, respectively. The derivatives of $\boldsymbol{u}(\boldsymbol{r})$ are the strain tensor and rotation for a small deformation:

$$
\varepsilon_{i j}=\frac{1}{2}\left(\frac{\partial u_{i}}{\partial x_{j}}+\frac{\partial u_{j}}{\partial u x_{i}}\right)
$$




$$
\boldsymbol{\omega}_{x y}=\frac{1}{2}\left(\frac{\partial u_{y}}{\partial x}-\frac{\partial u_{x}}{\partial y}\right)
$$

The strain tensor components shown in the GPA maps were obtained from HAADF-STEM images to obtain atomic resolution strain analysis. The c-TiN buffer layer was used as a reference because it has the minimum strain (i.e. the closest to the MgO substrates). Figure 6.3 below shows an example that both TiN and MgO have the minimum strain thus they can be used as reference for the GPA analysis. The amount of strain in the TiN buffer layer is almost like that of the $\mathrm{MgO}$, wherein no significant contrast variation is observed. When the $\mathrm{MgO}$ substrate is used as the reference instead of TiN, it has a very similar result. In Paper 3, the TiN buffer layer has been consistently used as the reference because it is closest to the film thus difference in foil thickness is more unlikely. The distinct spots in the FFTs of the high-resolution STEM images confirm that both buffer layer and film are in the same zone axis.
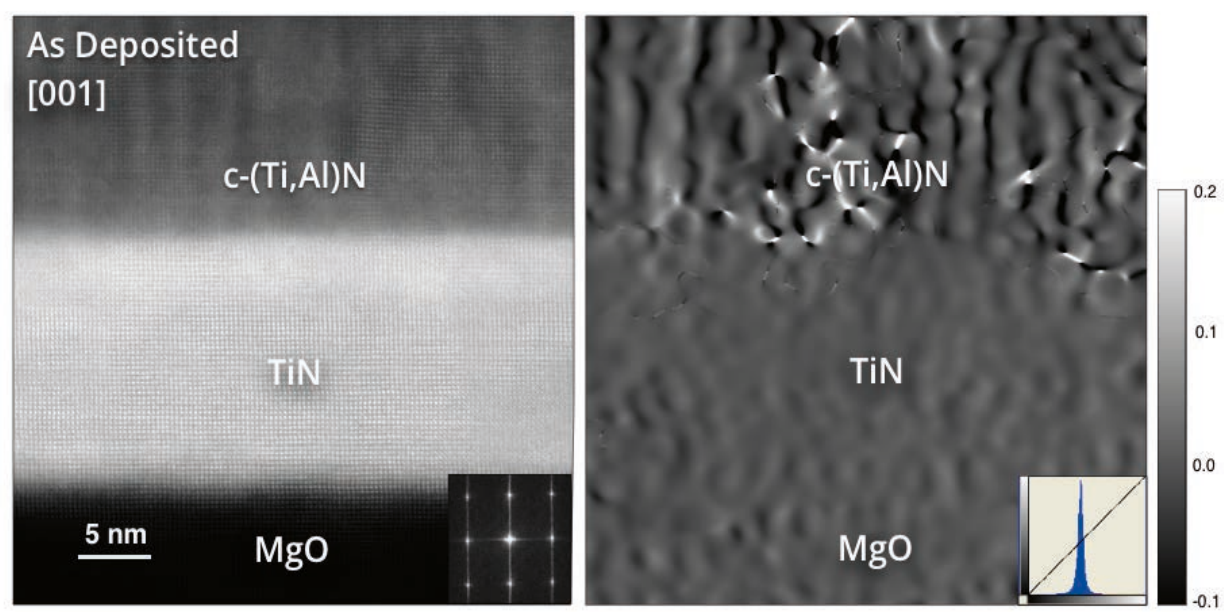

Figure 6.3. (a) HAADF-STEM with FFT inset and the corresponding deformation maps for (b) $\varepsilon_{\mathrm{xx}}$ strain tensor of as-deposited c-(Tio.38,Alo.62 $) \mathrm{N} / \mathrm{c}-\mathrm{TiN}(001)$.

\subsection{APT}

The chemical compositions of $\mathrm{c}-\left(\mathrm{Ti}_{1-\mathrm{x}} \mathrm{Al}_{\mathrm{x}}\right) \mathrm{N}_{\mathrm{y}}$ films were obtained from a local electrode atom probe (Cameca LEAP $3000 \mathrm{X}$ HR). The standard lift out technique [90] using FIB was used to produce the atom probe tomography (APT) tips. The tips were extracted at different positions along the thin film thickness. The tip shape was optimized to reduce the thermal tails and obtain high quality mass-to-charge spectra in APT. The composition analysis of the 
APT technique the sample is based on at least 10 million ions per tip and 5 to 10 tips were used for each composition determination. This resulted in differences between spectra of less than 1 at. \% of the elemental composition $(\mathrm{Al}, \mathrm{Ti}, \mathrm{N})$. The nitrogen per metal fraction and the $\mathrm{Al}$ metal fraction were calculated by using the atomic percentages of the three main elements ( $\mathrm{Al}, \mathrm{Ti}$ and N). The errors reported have two contributions: the statistical error obtained from the reconstruction program (IVAS) and the composition average obtained from measuring several tips at different positions along the thin film thickness (propagation of errors is included). The main contribution to the error is due to intrinsic fluctuation in the as deposited state as describe by frequency distribution analysis and Pearson coefficient in previous work $[14,91]$.

A proximity histogram (proxigram) was used to obtain the composition profiles across the interfaces of the decomposed Al- and Ti-rich domains. It is a data compilation technique that generates a composition profile in $3 \mathrm{D}$ relative and in the vicinity to a reference surface [92]. Based from Gault et. al [93], the general steps for generating a proxigrams in the reconstruction program (IVAS) are the following: first, the creation of an isosurface which highlights the microstructure feature to be analyzed. Then, the composition is examined normal to the isosurface in layers (shells) at increasing or decreasing distances, therefore no restriction in the surface geometry is imposed. Then, from each shell a concentration distribution profile (histogram) of each element present is generated. Finally, the data extracted from the histograms (average composition) is plotted as a proxigram composition profile.

\subsection{Nanoindentation}

The hardness values of the coatings were measured using UMIS nanoindenter and Hysitron Triboindenter TI-950 that are equipped with a Berkovich diamond tip. Polished tapered cross-sections of the coatings deposited using cathodic arc technique were used for the depth-sensing indentation while polished top surfaces were used for the coatings deposited using sputtering technique. At least 25 indents were performed for each sample. The Oliver and Pharr method [94] was used to determine the average hardness values that were extracted from the load-displacement curves. The contact area of the tip versus penetration depth was measured by using a fused silica as reference. 


\subsection{Thermal Analysis}

The differential scanning calorimetry (DSC) method is used to measure the enthalpy changes when heating a material. This is done by measuring the difference in energy input into a substance and a reference material as a function of temperature. The DSC curve was used to calculate enthalpies of transitions by integrating the peak corresponding to a given transition. In this study, the thermal response of the (Ti,Al)N powders (i.e extracted from the coatings deposited on the Fe foils [22]) was examined using Netsch STA 449C DSC. Two heating cycles were performed, in which the second cycle was used as the baseline correction.

\subsection{Ion beam analysis}

The atomic compositions of single crystalline ( $\mathrm{Ti}, \mathrm{Al}) \mathrm{N}$ coatings that were synthesized using different $\mathrm{N}$ flow rate were measured using ion-beam based material analysis. A $5 \mathrm{MV}{ }_{15} \mathrm{SDH}-2$ tandem accelerator at the Tandem Laboratory in Uppsala University was used for generation of ion beams. Timeof-flight elastic recoil detection analysis (TOF-ERDA) technique was used to determine the elemental distributions of the coatings. This is performed with a $36 \mathrm{MeV}{ }^{127} \mathrm{I}^{8+}$ beam with a recoil angle of $45^{\circ}$ and incident angle of $67.5^{\circ}$ with the surface normal. The Rutherford backscattering spectrometry (RBS) was used to determine the stoichiometry. This is performed with a $2 \mathrm{MeV} 4 \mathrm{He}^{+}$ beam with scattering angle of $170^{\circ}$, an incidence angle of $5^{\circ}$ with respect to the surface normal, and a wiggling algorithm during acquisition to minimize channeling effects on the crystalline substrate. 


\section{Summary of papers and contribution to the field}

\subsection{Paper 1}

This study tackles the influence of point defects generated during cathodic arc deposition on the phase stability and microstructural evolution of nitrogen deficient $\left(\mathrm{Ti}_{1-\mathrm{x}}, \mathrm{Al}_{\mathrm{x}}\right) \mathrm{N}_{\mathrm{y}}$ thin films. The influence of applied negative bias voltage on the point defect concentration (e.g. self-interstitials and anti-sites) in c$\left(\mathrm{Ti}_{0.54}, \mathrm{Al}_{0.46}\right)_{\mathrm{N}} \mathrm{N}_{\mathrm{g} 7}$ alloys and consequently the microstructural and mechanical properties at high temperatures were shown. The enhancement of the driving force for phase separation at high bias voltage of $-80 \mathrm{~V}$ was shown and attributed to the delayed annihilation of point defects resulting to an increase in internal energy of the system. The age hardening effect of the films is retained until $1100{ }^{\circ} \mathrm{C}$ (i.e. highest temperature reported for (Ti,Al)N films) by applying low bias voltage and reducing the overall $\mathrm{N}$ content of the coating during deposition. The results open up possible future design routes for transition metal nitride coatings and allow a better understanding on the effect of point defects that are generated in physical vapor deposition.

\subsection{Paper 2}

The main factors influencing the wear behavior of nitrogen deficient ( $\mathrm{Ti}_{1}$ $\left.\mathrm{x}, \mathrm{Al}_{\mathrm{x}}\right) \mathrm{N}_{\mathrm{y}}$ coatings during high-speed cutting of a steel workpiece are shown in this study. The optimum bias condition that was reported in Paper 1 was employed in synthesizing (Ti,Al)N films with different $\mathrm{N}$ contents. Then, the interplay of nitrogen vacancies, microstructure, and chemical reaction of c$\left(\mathrm{Ti}_{0.52}, \mathrm{Al}_{0.48}\right) \mathrm{N}_{\mathrm{y}}$ coatings with average $\mathrm{N}$ concentration of $\mathrm{y}=0.92, \mathrm{y}=0.87$, and $\mathrm{y}=0.75$ during cutting tests was investigated. The $\mathrm{y}=0.75$ coating contains the highest number of macroparticles and has an inhomogeneous microstructure after machining, containing $\mathrm{c}-\left(\mathrm{Ti}_{0.52}, \mathrm{Al}_{0.48}\right) \mathrm{N}_{\mathrm{y}}, \mathrm{Ti}_{2} \mathrm{AlN}$ MAX phases, and alternating layers of $\mathrm{AlN}$ and $\mathrm{Fe}-\mathrm{Ti}$ phases near the macroparticles. In this case, both the chemical alteration within the coating and the presence of macroparticles has contributed to its relatively low flank and crater wear resistance. The $\mathrm{y}=0.92$ sample has an earlier onset of spinodal decomposition to c-AlN and c-TiN- rich domains as compared to the other samples. This decomposed structure has misfit dislocations (as observed in Paper 3) that caused the accelerated diffusion of Fe and Co from the 
workpiece and the substrate though the coating, which would weaken the structure of the coating and make it more susceptible to wear. There is a delay in decomposition of the $y=0.87$ sample, which is caused by the presence of nitrogen vacancies that lowers the free energy of the system. The occurrence of age hardening in $\mathrm{y}=0.92$ sample has caused its superior flank wear resistance among the samples while the dense structure of $y=0.87$ sample that prevented chemical wear due to diffusion has caused its excellent crater wear resistance. This study gives insight on the role of nitrogen vacancies on the chemical reaction and wear behavior of transition metal nitride coatings during cutting service.

\subsection{Paper 3}

The defect structure of single crystal $c-\left(\mathrm{Ti}_{0.37}, \mathrm{Al}_{0.63}\right) \mathrm{N}$ during spinodal decomposition is discussed in this study. Heteroepitaxial c- $\left(\mathrm{Ti}_{0.37}, \mathrm{Al}_{0.63}\right) \mathrm{N}$ thin films were grown on $\mathrm{MgO}(001)$ and (111) substrates by magnetron sputtering. Single crystalline films with high level of purity allow the determination of the details of their dislocation structure using high-resolution diffraction and imaging techniques. The crystal quality of the single crystalline (Ti,Al)N films were examined by high-resolution XRD, reciprocal space maps (RSM), and high-angle annular dark-field imaging scanning transmission electron micrographs (HAADF-STEM). RSM measurements show that the annealed film (i.e. undergoes spinodal decomposition) has lower lateral correlation, broader FWHM and higher mosaicity as compared to the as-deposited film. HAADF-STEM images show that as-deposited films have homogeneous composition with no indication of elemental segregation while annealed films decompose to form coherent c-AlN- and c-TiN- rich domains with elongated shape along the elastically soft <001> direction. The deformation maps containing the strain tensor components (e.g. $\varepsilon_{\mathrm{xx}}, \varepsilon_{\mathrm{yy}}$, and $\varepsilon_{\mathrm{xy}}$ ) of $c$-(Ti,Al)N were shown for the first time in this study through geometric phase analysis (GPA) on HAADF-STEM micrographs. Results reveal that strains occur near the interface of the segregated domains and the c-TiN domains accommodate more dislocations than the c-AlN domains. This is attributed to the strong directionality of the covalent chemical bonds of c-AlN, making the dislocations favorably aggregate in c-TiN. The findings point out that the chemical bonding state and elastic properties of the segregated domains affects the defect structure of (Ti,Al)N during spinodal decomposition. 


\subsection{Paper 4}

Epitaxial growth of wurtzite $\mathrm{w}-\left(\mathrm{Ti}_{0.23}, \mathrm{Al}_{0.77}\right) \mathrm{N}(0001)$ film on $\mathrm{MgO}(111)$ substrate has been shown for the first time in this study. The film was grown at $700{ }^{\circ} \mathrm{C}$ using a UHV DC magnetron sputtering system. A single crystal cubic c$\left(\mathrm{Ti}_{0.23}, \mathrm{Al}_{0.77}\right) \mathrm{N}$ film is first grown to a critical thickness (between 10 and $30 \mathrm{~nm}$ ) using a TiN(111) buffer layer deposited on $\mathrm{MgO}(111)$. Above this thickness, a transition from cubic to wurtzite film occurs, with a zigzag interface between the two structures. The interface has orientation relationship of $\mathrm{c}$ $\left(\mathrm{Ti}_{0.23}, \mathrm{Al}_{0.77}\right) \mathrm{N}(111)[1 \overline{1} 0]|| \mathrm{w}-\left(\mathrm{Ti}_{0.23}, \mathrm{Al}_{0.77}\right) \mathrm{N}(0001)[11 \overline{2} 0] . \quad$ Continued deposition results to a gradual break-down of the epitaxial growth towards polycrystalline growth of wurtzite columns with a high degree of 0001 texture. Plan-view TEM images show that the wurtzite grains grow larger as the film thickens.

This study also compares the thermal stability of epitaxial w$\left(\mathrm{Ti}_{0.23}, \mathrm{Al}_{0.77}\right) \mathrm{N}(0001)$ and epitaxial c-(Ti $\left.\mathrm{T}_{0.37}, \mathrm{Al}_{0.63}\right) \mathrm{N}(111)$. The as-deposited $\mathrm{w}-$ $\left(\mathrm{Ti}_{0.23}, \mathrm{Al}_{0.77}\right) \mathrm{N}(\mathrm{oo01})$ shows a clustering of coherent $\mathrm{nm}$-sized domains while c$\left(\mathrm{Ti}_{0.37}, \mathrm{Al}_{\text {o.63 }}\right) \mathrm{N}(111)$ remains homogeneous. After annealing at $900{ }^{\circ} \mathrm{C}$, the cubic film has segregated to form elongated c-AlN and c-TiN- rich domains along [oo1] direction via spinodal decomposition (i.e as reported in Paper 3) while the wurtzite film has domains with slightly larger sizes than that of the asdeposited. The wurtzite structure has a slower coarsening rate of the compared to cubic, which is indicative of a higher thermal stability.

\subsection{Paper 5}

Epitaxial $\left(\mathrm{Ti}_{1-\mathrm{x}}, \mathrm{Al}_{\mathrm{x}}\right) \mathrm{N}_{\mathrm{y}}$ with average $\mathrm{N}$ concentration of $\mathrm{y}=0.67,0.79$, and 0.92 are deposited on (111)- and (o01)- oriented $\mathrm{MgO}$ substrates by DC magnetron sputtering technique. Epitaxial c- $\left(\mathrm{Ti}_{1-\mathrm{x}}, \mathrm{Al}_{\mathrm{x}}\right) \mathrm{N}_{\mathrm{y}}(111)$ on $\mathrm{MgO}(111)$ is sustained all through the film thickness. Epitaxial c- $\left(\mathrm{Ti}_{1-\mathrm{x}}, \mathrm{Al}_{\mathrm{x}}\right) \mathrm{N}_{\mathrm{y}}(\mathrm{Oo1})$ layers are grown on $\mathrm{MgO}(001)$ for a certain thickness (few nanometers) then a transition to polycrystalline growth occurs. The thickness of epitaxial c- $\left(\mathrm{Ti}_{1-\mathrm{x}}, \mathrm{Al}_{\mathrm{x}}\right) \mathrm{N}_{\mathrm{y}}(\mathrm{OO1})$ layer increases as the $\mathrm{N}$ content decreases. The better crystalline quality of films with low $\mathrm{N}$ contents is attributed to the high adatom surface mobility in $\mathrm{N}$ deficient conditions. The epitaxial c-(Ti,Al)N(111) and c-(Ti,Al)N(o01) layers are homogeneous in the as-deposited state. The strain maps of the HAADFSTEM images of epitaxial $c-\left(\mathrm{Ti}_{1-\mathrm{x}} \mathrm{Al}_{\mathrm{x}}\right) \mathrm{N}_{\mathrm{y}}$ (111) films show that films with higher $\mathrm{N}$ vacancies have more strain fluctuation. After annealing at $950{ }^{\circ} \mathrm{C}$, the c(Ti,Al)N(111) films have undergone spinodal decomposition. The domain size 
of (oo1) and (111)- oriented epitaxial c-(Ti,Al)N films increases with the nitrogen content. Strain maps show that decomposition increase the strain fluctuation of the system. The coherency strain and dislocations generated during decomposition resulted to an increase in hardness of the films. Annealing the films at $1100{ }^{\circ} \mathrm{C}$ have caused the domain sizes of the films to further increase and the strain concentration to decrease. At this temperature, the hardness of the $y=0.79$, and 0.92 films have decreased because the coherency has decreased when the domains have coarsen. Whilst, the hardness of the $y=0.67$ film still increase because there is a delay in coarsening with high $\mathrm{N}$ vacancies.

Unique features are observed in $\left(\mathrm{Ti}_{1-\mathrm{x}}, \mathrm{Al}_{\mathrm{x}}\right) \mathrm{N}_{0.67}$ films, which has the highest $\mathrm{N}$ vacancies. The $\left(\mathrm{Ti}_{1-\mathrm{x}}, \mathrm{Al}_{\mathrm{x}}\right) \mathrm{N}_{0.67}(111)$ film on $\mathrm{MgO}(111)$ contains some coherently oriented wurtzite $\mathrm{w}-\left(\mathrm{Ti}_{1-\mathrm{x}}, \mathrm{Al}_{\mathrm{x}}\right) \mathrm{N}_{0.67}(\mathrm{OOO1})$ structure in some regions at the top of the film. The $\left(\mathrm{Ti}_{1-\mathrm{x}}, \mathrm{Al}_{\mathrm{x}}\right) \mathrm{N}_{0.67}(\mathrm{OO1})$ film on $\mathrm{MgO}(\mathrm{OO1})$ contains conical features with segregated domains already in the as-deposited state and remains stable when annealed at $950{ }^{\circ} \mathrm{C}$. The domain size of this film has slightly increased after annealing at $1100{ }^{\circ} \mathrm{C}$. The coarsening rate of the domains inside the conical feature is slower than that of the domains in the epitaxial layer at high temperatures. $\mathrm{N}$ vacancy concentration affects the defect structures and thermal stability of $\left(\mathrm{Ti}_{1-\mathrm{x}}, \mathrm{Al}_{\mathrm{x}}\right) \mathrm{N}_{\mathrm{y}}$ thin films. 


\section{Future work}

The potential research works based on the results obtained in this thesis are the following:

- Cathodic arc deposited films. A delay in decomposition is observed as $\mathrm{N}$ content of $\left(\mathrm{Ti}_{0.5}, \mathrm{Al}_{0.5}\right) \mathrm{N}_{\mathrm{y}}(\mathrm{y}<1)$ films decreases. This results to a higher thermal stability (Paper 1) and crater wear resistance (Paper 2) of nitrogen deficient films. However, low $\mathrm{N}$ content of films also results to an increase in the number of macroparticles, which is detrimental to the mechanical properties of the coatings. The presence of macroparticles also facilitates diffusion of chip elements into the coatings during machining and causes chemical wear. Filtered cathodic arc system is recommended to minimize macroparticles of $\left(\mathrm{Ti}_{0.5}, \mathrm{Al}_{0.5}\right) \mathrm{N}_{\mathrm{y}}(\mathrm{y}<1)$ films and further improve their functional properties.

- Elastic Properties. In Paper 1 and Paper 3, ab initio cubic elastic constants are used for the strain measurements. It is recommended to use experimental techniques to measure elastic constants of the single crystal c-( $\left(\mathrm{Ti}_{1-\mathrm{x}}, \mathrm{Al}_{\mathrm{x}}\right) \mathrm{N}_{\mathrm{y}}$ films such as by TEM and optical characterizations. Elastic constants of wurtzite $\left(\mathrm{Ti}_{1-\mathrm{x}}, \mathrm{Al}_{\mathrm{x}}\right) \mathrm{N}_{\mathrm{y}}$ are missing in the literature. These are needed to obtain more information on the elastic properties of this structure.

- Wurtzite (Ti,Al)N

- In Paper 4, the growth and microstructural features at high temperature of epitaxial $\mathrm{w}-\left(\mathrm{Ti}_{1-\mathrm{x}}, \mathrm{Al}_{\mathrm{x}}\right) \mathrm{N}_{\mathrm{y}}(111)$ film have been shown. Theoretical studies on the microstructural and strain evolution of single crystal $\mathrm{w}$-(Ti,Al)N should be investigated. Besides hardness, functional properties of this structure such as thermal and electrical conductivities are of interest.

- In Paper 5, experimental studies show the formation of wurtzite structures in $\left(\mathrm{Ti}_{1-\mathrm{x}}, \mathrm{Al}_{\mathrm{x}}\right) \mathrm{N}_{\mathrm{y}}$ film with high $\mathrm{N}$ vacancies on $\mathrm{MgO}(111)$ substrate. Theoretical calculations on the effect of $\mathrm{N}$ vacancies and other defects (e.g. interstitials, anti-sites, and line defects) on the thermodynamics and kinetics of w(Ti,Al)N should be investigated. 
- In-situ decomposition studies. In Paper 5, N vacancies concentration has effect on the coarsening rate of the Ti- and Al- rich domains in $\left(\mathrm{Ti}_{1-\mathrm{x}}, \mathrm{Al}_{\mathrm{x}}\right) \mathrm{N}_{\mathrm{y}}$ single crystal films.

- It is recommended to do STEM imaging and chemical analysis during annealing of single crystal films with different $\mathrm{N}$ contents in order to obtain more details on the microstructural evolution and chemical composition of domains during decomposition. Visualization on how $\mathrm{N}$ vacancies affect decomposition kinetics is important.

- It is of interest to investigate the dislocation structure and strain evolution of single crystal films during annealing. These would provide us more insight on how dislocations can affect the kinetics and thermodynamics of $c-\left(\mathrm{Ti}_{1-\mathrm{x}}, \mathrm{Al}_{\mathrm{x}}\right) \mathrm{N}_{\mathrm{y}}$ at elevated temperatures.

\section{- Deformation Mechanism}

- Detailed studies of the plastic zone in single crystal c-(Ti$\left.{ }_{x}, \mathrm{Al}_{\mathrm{x}}\right) \mathrm{N}_{\mathrm{y}}$ films induced by nanoindentation is recommended. Characterizations can be done by TEM.

- It is recommended to synthesize $\mathrm{w}-\left(\mathrm{Ti}_{1-\mathrm{x}}, \mathrm{Al}_{\mathrm{x}}\right) \mathrm{N}_{\mathrm{y}}$ single crystal films with different growth orientations and evaluate its deformation mechanism.

- Material Systems. It is recommended to investigate in detail the dislocation structure, effect of point defects, and strain evolution of other transition metal nitrides (e.g. Zr, Ta, and Hf nitrides), high entropy alloys, and multilayers. This can be done by utilizing the stateof-the-art techniques used in this study such as high resolution XRD, TEM, and GPA analysis.

- Applications. The performance of the synthesized polycrystalline $(\mathrm{Ti}, \mathrm{Al}) \mathrm{N}$ coatings during cutting tests has been investigated in this study. The synthesized single crystalline cubic and wurtzite (Ti,Al)N films have potential applications in electronics and semiconductor industries. 


\section{References}

[1] G. Welsch, R. Boyer, E. Collings, Materials properties handbook: titanium alloys, ASM international 1993.

[2] P.D. Harvey, Engineering properties of steel, American Society for Metals Metals Park, OH 1982.

[3] P. Jindal, A. Santhanam, U. Schleinkofer, A. Shuster, Performance of PVD TiN, TiCN, and TiAlN coated cemented carbide tools in turning, Int. J. Refract. Met. Hard Mater., 17 (1999) 163-170.

[4] H. Holleck, Material selection for hard coatings, J. Vac. Sci. Technol., A 4(1986) 2661-2669.

[5] J. Musil, Hard and superhard nanocomposite coatings, Surf. Coat. Technol., 125 (2000) 322-330.

[6] S. PalDey, S. Deevi, Single layer and multilayer wear resistant coatings of (Ti, Al) N: a review, Mater. Sci. Eng., A 342 (2003) 58-79.

[7] H. Holleck, H. Schulz, Advanced layer material constitution, Thin Solid Films, 153 (1987) 11-17.

[8] P.H. Mayrhofer, A. Hörling, L. Karlsson, J. Sjölén, T. Larsson, C. Mitterer, L. Hultman, Self-organized nanostructures in the Ti-Al-N system, Appl. Phys. Lett., 83 (2003) 2049-2051.

[9] M. Oden, L. Rogström, A. Knutsson, M. Terner, P. Hedström, J. Almer, J. Ilavsky, In situ small-angle $x$-ray scattering study of nanostructure evolution during decomposition of arc evaporated TiAlN coatings, Appl. Phys. Lett., 94 (2009) 053114.

[10] I.A. Abrikosov, A. Knutsson, B. Alling, F. Tasnádi, H. Lind, L. Hultman, M. Odén, Phase stability and elasticity of TiAlN, Materials, 4 (2011) 1599-1618.

[11] S.T. Oyama, Introduction to the chemistry of transition metal carbides and nitrides, The chemistry of transition metal carbides and nitrides, Springer 1996, pp. 1-27.

[12] J. Margrave, L. Toth, Transition metal carbides and Nitrides, Academic Press, New York, 1971.

[13] B. Alling, A. Karimi, L. Hultman, I.A. Abrikosov, First-principles study of the effect of nitrogen vacancies on the decomposition pattern in cubic Ti1-xAlxN1-y, Appl. Phys. Lett., 92 (2008) 071903.

[14] I.C. Schramm, M.P. Johansson Jõesaar, J. Jensen, F. Mücklich, M. Odén, Impact of nitrogen vacancies on the high temperature behavior of (Ti1-xAlx)Ny alloys, Acta Mater., 119 (2016) 218-228. 
[15] I.C. Schramm, C. Pauly, M.P. Johansson Jõesaar, S. Slawik, S. Suarez, F. Mücklich, M. Odén, Effects of nitrogen vacancies on phase stability and mechanical properties of arc deposited (Tio.52Alo.48)Ny (y<1) coatings, Surf. Coat. Technol., 330 (2017) 77-86.

[16] W.D. Münz, Titanium aluminum nitride films: A new alternative to TiN coatings, J. Vac. Sci. Technol., A 4 (1986) 2717-2725.

[17] Q. Chen, B. Sundman, Thermodynamic assessment of the Ti-Al-N system, Journal of Phase Equilibria, 19 (1998) 146.

[18] M. Ohring, Materials science of thin films, Elsevier 2001.

[19] N. Shulumba, O. Hellman, Z. Raza, B. Alling, J. Barrirero, F. Mücklich, I.A. Abrikosov, M. Odén, Lattice Vibrations Change the Solid Solubility of an Alloy at High Temperatures, Phys. Rev. Lett., 117 (2016) 205502.

[20] B. Alling, A.V. Ruban, A. Karimi, O.E. Peil, S. Simak, L. Hultman, I. Abrikosov, Mixing and decomposition thermodynamics of $\mathrm{c}-\mathrm{Ti} 1-\mathrm{x} \mathrm{Al} \times \mathrm{N}$ from first-principles calculations, Phys. Rev. B, 75 (2007) 045123.

[21] B. Alling, M. Odén, L. Hultman, I. Abrikosov, Pressure enhancement of the isostructural cubic decomposition in Ti1-xAlxN, Appl. Phys. Lett., 95 (2009) 181906.

[22] N. Norrby, H. Lind, G. Parakhonskiy, M.P. Johansson, F. Tasnádi, L.S. Dubrovinsky, N. Dubrovinskaia, I.A. Abrikosov, M. Odén, High pressure and high temperature stabilization of cubic AlN in Tio.60Alo.40N, J. Appl. Phys., 113 (2013) 053515.

[23] D. Holec, F. Rovere, P.H. Mayrhofer, P.B. Barna, Pressure-dependent stability of cubic and wurtzite phases within the TiN-AlN and CrN-AlN systems, Scripta Mater., 62 (2010) 349-352.

[24] F.C. Campbell, Elements of metallurgy and engineering alloys, ASM International 2008.

[25] G.N. Haidemenopoulos, Physical Metallurgy: Principles and Design, CRC Press 2018.

[26] D. Porter, K. Esterling, Phase transformations, Metals and Alloys, second ed., Chapman \& Hall, London 1992.

[27] J.W. Cahn, J.E. Hilliard, Free energy of a nonuniform system. I. Interfacial free energy, The Journal of chemical physics, 28 (1958) 258-267.

[28] R. Haskell, Introduction to the thermodynamics of spinodal decomposition, Journal of the American Ceramic Society, 56 (1973) 355-360.

[29] A. Knutsson, M. Johansson, P.Å. Persson, L. Hultman, M. Odén, Thermal decomposition products in arc evaporated TiAlN/TiN multilayers, Appl. Phys. Lett., 93 (2008) 143110. 
[30] N. Norrby, L. Rogström, M.P. Johansson-Jõesaar, N. Schell, M. Odén, In situ Xray scattering study of the cubic to hexagonal transformation of AlN in Ti1-xAlxN, Acta Mater., 73 (2014) 205-214.

[31] A. Knutsson, M. Johansson, L. Karlsson, M. Odén, Thermally enhanced mechanical properties of arc evaporated Tio.34Alo.66N/TiN multilayer coatings, J. Appl. Phys., 108 (2010) 044312.

[32] R. Rachbauer, S. Massl, E. Stergar, D. Holec, D. Kiener, J. Keckes, J. Patscheider, M. Stiefel, H. Leitner, P. Mayrhofer, Decomposition pathways in age hardening of TiAl-N films, J. Appl. Phys., 110 (2011) 023515.

[33] F. Wang, I.A. Abrikosov, S.I. Simak, M. Odén, F. Mücklich, F. Tasnádi, Coherency effects on the mixing thermodynamics of cubic Ti $1-\mathrm{x} \mathrm{Al} \mathrm{x} \mathrm{N/TiN} \mathrm{(oo1)} \mathrm{multilayers,}$ Phys. Rev. B, 93 (2016) 174201.

[34] F. Tasnádi, I.A. Abrikosov, L. Rogström, J. Almer, M.P. Johansson, M. Odén, Significant elastic anisotropy in Ti1-xAlxN alloys, Appl. Phys. Lett., 97 (2010) 231902.

[35] N. Shulumba, O. Hellman, L. Rogström, Z. Raza, F. Tasnádi, I.A. Abrikosov, M. Odén, Temperature-dependent elastic properties of Ti1-xAlxN alloys, Appl. Phys. Lett., 107 (2015) 231901.

[36] A. Hörling, L. Hultman, M. Odén, J. Sjölén, L. Karlsson, Thermal stability of arc evaporated high aluminum-content Ti1-xAlxN thin films, J. Vac. Sci. Technol., A 20 (2002) 1815-1823.

[37] N. Engel, Copper, copper alloys and the electron concentration concept, Acta Metallurgica, 15 (1967) 557-563.

[38] S. Uehara, T. Masamoto, A. Onodera, M. Ueno, O. Shimomura, K. Takemura, Equation of state of the rocksalt phase of III-V nitrides to $72 \mathrm{GPa}$ or higher, Journal of Physics and Chemistry of Solids, 58 (1997) 2093-2099.

[39] T. Sasaki, M. Akaishi, S. Yamaoka, Y. Fujiki, T. Oikawa, Simultaneous crystallization of diamond and cubic boron nitride from the graphite relative boron carbide nitride $\left(\mathrm{BC}_{2} \mathrm{~N}\right)$ under high pressure/high temperature conditions, Chemistry of Materials, 5 (1993) 695-699.

[40] M. Garbrecht, L. Hultman, M. Fawey, T. Sands, B. Saha, Void-mediated coherency-strain relaxation and impediment of cubic-to-hexagonal transformation in epitaxial metastable metal/semiconductor TiN/Alo.72Sc0.28N multilayers, Physical Review Materials, 1 (2017) 033402.

[41] M. Zhou, Y. Makino, M. Nose, K. Nogi, Phase transition and properties of Ti-Al-N thin films prepared by r.f.-plasma assisted magnetron sputtering, Thin Solid Films, 339 (1999) 203-208.

[42] Y. Pinot, M.H. Tuilier, M.J. Pac, C. Rousselot, D. Thiaudière, C. Ulhaq-Bouillet, Influence of film thickness on the structural transition cubic/hexagonal within Tio.38Alo.62N films, Thin Solid Films, 649 (2018) 160-166. 
[43] U. Wahlström, L. Hultman, J.E. Sundgren, F. Adibi, I. Petrov, J.E. Greene, Crystal growth and microstructure of polycrystalline Ti1-xAlxN alloy films deposited by ultrahigh-vacuum dual-target magnetron sputtering, Thin Solid Films, 235 (1993) 62-70.

[44] R. Rachbauer, J.J. Gengler, A.A. Voevodin, K. Resch, P.H. Mayrhofer, Temperature driven evolution of thermal, electrical, and optical properties of $\mathrm{Ti}-\mathrm{Al}-\mathrm{N}$ coatings, Acta Mater., 60 (2012) 2091-2096.

[45] K. Calamba, J. Barrirero, M.P. Johansson Jõesaar, S. Bruyère, J. Pierson, A.l. Febvrier, P. Eklund, F. Mücklich, R. Boyd, M. Odén, Growth and high temperature decomposition of epitaxial metastable wurtzite (Ti1-x,Alx)N(0001) thin films, (Unpublished results).

[46] L. Toth, Transition metal carbides and nitrides, Elsevier 2014.

[47] F. Burmeister, C. Kohn, R. Kuebler, G. Kleer, B. Bläsi, A. Gombert, Applications for TiAlN- and TiO2-coatings with nanoscale surface topographies, Surf. Coat. Technol., 200 (2005) 1555-1559.

[48] H. Ljungcrantz, M. Odén, L. Hultman, J. Greene, J.E. Sundgren, Nanoindentation studies of single-crystal (001)-,(011)-, and (111)-oriented TiN layers on MgO, J. Appl. Phys., 80 (1996) 6725-6733.

[49] F. Adibi, I. Petrov, L. Hultman, U. Wahlström, T. Shimizu, D. McIntyre, J. Greene, J.E. Sundgren, Defect structure and phase transitions in epitaxial metastable cubic Tio. 5Alo. $5 \mathrm{~N}$ alloys grown on $\mathrm{MgO}$ (001) by ultra-high-vacuum magnetron sputter deposition, J. Appl. Phys., 69 (1991) 6437-6450.

[50] M. to Baben, L. Raumann, D. Music, J.M. Schneider, Origin of the nitrogen overand understoichiometry in Tio.5Alo.5N thin films, J Phys-Condens Mat, 24 (2012) 155401.

[51] M. to Baben, M. Hans, D. Primetzhofer, S. Evertz, H. Ruess, J.M. Schneider, Unprecedented thermal stability of inherently metastable titanium aluminum nitride by point defect engineering, Mater. Res. Lett., 5:3 (2016) 158-169.

[52] H. Oettel, R. Wiedemann, S. Preißler, Residual stresses in nitride hard coatings prepared by magnetron sputtering and arc evaporation, Surf. Coat. Technol., 74 (1995) 273-278.

[53] L. Tsetseris, N. Kalfagiannis, S. Logothetidis, S.T. Pantelides, Role of N Defects on Thermally Induced Atomic-Scale Structural Changes in Transition-Metal Nitrides, Phys. Rev. Lett. , 99 (2007) 125503.

[54] K. Calamba, I. Schramm, M. Johansson Jõesaar, J. Ghanbaja, J. Pierson, F. Mücklich, M. Odén, Enhanced thermal stability and mechanical properties of nitrogen deficient titanium aluminum nitride (Tio.54Alo.46Ny) thin films by tuning the applied negative bias voltage, J. Appl. Phys., 122 (2017) 065301. 
[55] D. Rafaja, C. Wüstefeld, C. Baehtz, V. Klemm, M. Dopita, M. Motylenko, C. Michotte, M. Kathrein, Effect of Internal Interfaces on Hardness and Thermal Stability of Nanocrystalline Tio.5Alo.5N Coatings, Metall. Mater. Trans. A, 42 (2011) 559-569.

[56] L. Rogström, J. Ullbrand, J. Almer, L. Hultman, B. Jansson, M. Odén, Strain evolution during spinodal decomposition of TiAlN thin films, Thin Solid Films, 520 (2012) 5542-5549.

[57] Y.-S. Li, S.-X. Li, T.-Y. Zhang, Effect of dislocations on spinodal decomposition in $\mathrm{Fe}-\mathrm{Cr}$ alloys, Journal of Nuclear Materials, 395 (2009) 120-130.

[58] A. Minami, A. Onuki, Dislocation formation in two-phase alloys, Phys. Rev. B, 70 (2004) 184114.

[59] C. Shen, N. Zhou, Y. Wang, Phase Field Modeling of Microstructural Evolution in Solids: Effect of Coupling among Different Extended Defects, Metall. Mater. Trans. A, 39 (2008) 1630-1637.

[6o] B. Muhammad, and R. Rahmatalla, Growth and Characterization of Metastable Wide and-gap AllnN Epilayers, Dissertation No. 1027, Linkoping University Press 2008.

[61] H. Larsson, Growth of Thick GaN Layers on Sapphire by Hydride Vapour Phase Epitaxy, Dissertation No. 958, Linkoping University Press 2005.

[62] K. Calamba, J. Pierson, S. Bruyère, A.l. Febvrier, P. Eklund, J. Barrirero, F. Mücklich, R. Boyd, M.P. Johansson Jõesaar, M. Odén, Dislocation structure and microstrain evolution during spinodal decomposition of reactive magnetron sputtered heteroepixatial c-(Tio.36,Alo.64)N/c-TiN films grown on $\mathrm{MgO}(001)$ and (111) substrates, J. Appl. Phys., 125 (2019) 105301.

[63] A. Anders, Cathodic arcs: from fractal spots to energetic condensation. Springer Science \& Business Media, 50 (2009).

[64] A.A. Snaper, Arc deposition process and apparatus, U.S. Patent 3,625,848 (1971).

[65] T. Utsumi, Measurements of cathode spot temperature in vacuum arcs, Appl. Phys. Lett., 18 (1971) 218-220.

[66] A. Anders, B. Yotsombat, R. Binder, Correlation between cathode properties, burning voltage, and plasma parameters of vacuum arcs, J. Appl. Phys., 89 (2001) 7764-7771.

[67] K.M. Calamba, M.P. Johansson Jõesaar, S. Bruyère, J.F. Pierson, R. Boyd, J.M. Andersson, M. Odén, The effect of nitrogen vacancies on initial wear in arc deposited (Tio.52,Alo.48)Ny, $(\mathrm{y}<1)$ coatings during machining, Surf. Coat. Technol., 358 (2019) 452-460. 
[68] I.C. Schramm, C. Pauly, M.P. Johansson Jõesaar, S. Slawik, S. Suarez, F. Mücklich, M. Odén, Effects of nitrogen vacancies on phase stability and mechanical properties of arc deposited (Tio.52Alo.48)Ny (y<1) coatings, Surf. Coat. Technol., 330 (2017) 77-86.

[69] W. Münz, D. Lewis, S. Creasey, T. Hurkmans, T. Trinh, W. Ijzendorn, Defects in TiN and TiAIN coatings grown by combined cathodic arc/unbalanced magnetron technology, Vacuum, 46 (1995) 323-330.

[70] R.L. Boxman, S. Goldsmith, Macroparticle contamination in cathodic arc coatings: generation, transport and control, Surf. Coat. Technol., 52 (1992) 39-50.

[71] K. Calamba, J. Salamania, M.P. Johansson Jõesaar, R. Boyd, S. Bruyère, J. Pierson, M.A. Sortica, D. Primetzhofer, M. Odén, Effect of vacancies on the dislocation structure and thermal stability of nitrogen deficient single crystal (Ti1-x,Alx)Ny thin films, (Unpublished results).

[72] K.K. Schuegraf, Handbook of thin-film deposition processes and techniques: principles, methods, equipment, and applications, Noyes Data Corporation/Noyes Publications1988.

[73] R.V. Stuart, Vacuum technology, thin films, and sputtering: an introduction, Academic Press 2012.

[74] A. Ingason, F. Magnus, S. Olafsson, J. Gudmundsson, Morphology of TiN thin films grown on $\mathrm{MgO}$ (oo1) by reactive de magnetron sputtering, J. Vac. Sci. Technol., A 28 (2010) 912-915.

[75] A. McLeod, C. Gabryel, Kinetics of the growth of spinel, MgAl2O4, on alumina particulate in aluminum alloys containing magnesium, Metall. Trans. A 23 (1992) 12791283 .

[76] B. Kramer, N. Suh, Tool wear by solution: a quantitative understanding, Journal of Engineering for Industry, 102 (1980) 303-309.

[77] B.V. Manoj Kumar, J.R. Kumar, B. Basu, Crater wear mechanisms of TiCN-NiWC cermets during dry machining, Int. J. Refract. Met. Hard Mater. , 25 (2007) 392399.

[78] S. Ruppi, M. Halvarsson, TEM investigation of wear mechanisms during metal machining, Thin Solid Films, 353 (1999) 182-188.

[79] D.A. Stephenson, J.S. Agapiou, Metal cutting theory and practice, CRC press 2016.

[8o] R. M'Saoubi, S. Ruppi, Wear and thermal behaviour of CVD a-Al2O3 and MTCVD Ti(C,N) coatings during machining, CIRP Annals, 58 (2009) 57-60.

[81] N. Norrby, M.P. Johansson, R. M'Saoubi, M. Odén, Pressure and temperature effects on the decomposition of arc evaporated Tio.6Alo.4N coatings in continuous turning, Surf. Coat. Technol. , 209 (2012) 203-207. 
[82] S. Ruppi, B. Ho" grelius, M. Huhtiranta, Wear characteristics of TiC, Ti(C,N), TiN and $\mathrm{Al}_{2} \mathrm{O}_{3}$ coatings in the turning of conventional and Ca-treated steels, Int. J. Refract. Met. Hard Mater., 16 (1998) 353-368.

[83] N. Norrby, M.P. Johansson-Jõesaar, M. Odén, Improved metal cutting performance with bias-modulated textured Tio.50Alo.50N multilayers, Surf. Coat. Technol., 257 (2014) 102-107.

[84] M.W. Barsoum, T. El-Raghy, M. Ali, Processing and characterization of Ti2AlC, Ti2AlN, and Ti2AlCo.5No.5, Metall. Mater. Trans. A, 31 (2000) 1857-1865.

[85] S. Veprek, M.G.J. Veprek-Heijman, P. Karvankova, J. Prochazka, Different approaches to superhard coatings and nanocomposites, Thin Solid Films, 476 (2005) 129.

[86] M. Birkholz, Thin film analysis by X-ray scattering, John Wiley \& Sons20o6.

[87] R. Langford, A.J.J.o.V.S. Petford-Long, S. Technology A: Vacuum, Films, Preparation of transmission electron microscopy cross-section specimens using focused ion beam milling, 19 (2001) 2186-2193.

[88] H. Rösner, C.T. Koch, G. Wilde, Strain mapping along Al-Pb interfaces, Acta Mater., 58 (2010) 162-172.

[89] M.J. Hÿtch, E. Snoeck, R. Kilaas, Quantitative measurement of displacement and strain fields from HREM micrographs, Ultramicroscopy, 74 (1998) 131-146.

[9o] K. Thompson, D. Lawrence, D.J. Larson, J.D. Olson, T.F. Kelly, B. Gorman, In situ site-specific specimen preparation for atom probe tomography, Ultramicroscopy, 107 (2007) 131-139.

[91] L.J.S. Johnson, M. Thuvander, K. Stiller, M. Odén, L. Hultman, Spinodal decomposition of Tio.33Alo.67N thin films studied by atom probe tomography, Thin Solid Films, 520 (2012) 4362-4368.

[92] O.C. Hellman, J.A. Vandenbroucke, J. Rüsing, D. Isheim, D.N. Seidman, Analysis of Three-dimensional Atom-probe Data by the Proximity Histogram, Microsc. Microanal., 6 (2002) 437-444.

[93] B. Gault, M.P. Moody, J.M. Cairney, S.P. Ringer, Atom probe microscopy, Springer Science \& Business Media 2012.

[94] W.C. Oliver, G.M. Pharr, An improved technique for determining hardness and elastic modulus using load and displacement sensing indentation experiments, Journal of Materials Research, 7 (2011) 1564-1583. 



\section{Papers}

The papers associated with this thesis have been removed for copyright reasons. For more details about these see:

http://urn.kb.se/resolve?urn=urn:nbn:se:liu:diva-157078 


\section{FACULTY OF SCIENCE AND ENGINEERING}

Linköping Studies in Science and Technology, Dissertation No. 1996, 2019

Department of Physics, Chemistry and Biology (IFM)

Linköping University

SE-581 83 Linköping, Sweden

www.liu.se 